U tvecklingsingenjörsprogrammet 22,5 hp

HÖGSKOLAN

I HALMSTAD
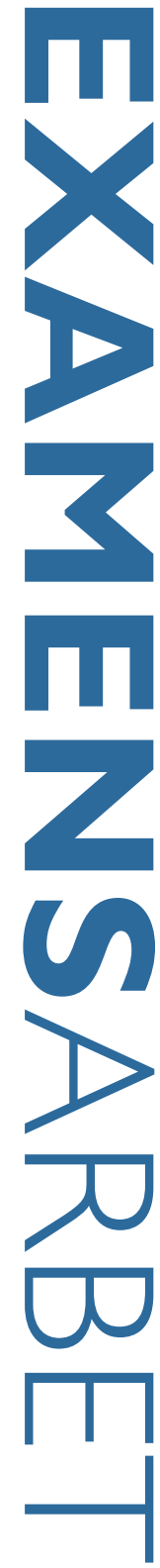



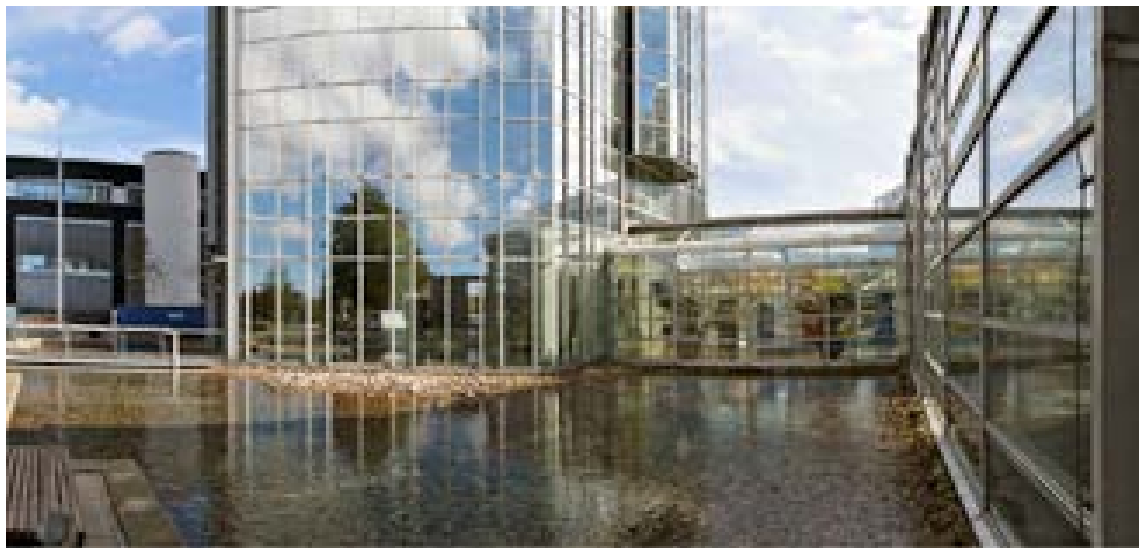

Collective Communication

Anna W estberg och Emma Bäckman

Examensarbete inom produktutveckling och innovationsledning

H almstad 2016-05-21 
DEN 21 MAJ 2016

\section{COLLECTIVE COMMUNICATION} EXAMENSARBETE - HÖGSKOLAN I HALMSTAD

ANNA WESTBERG EMMA BÄCKMAN

EXAMINATOR: LEIF NORDIN HANDLEDARE: HANS-ERIK ELDEMARK

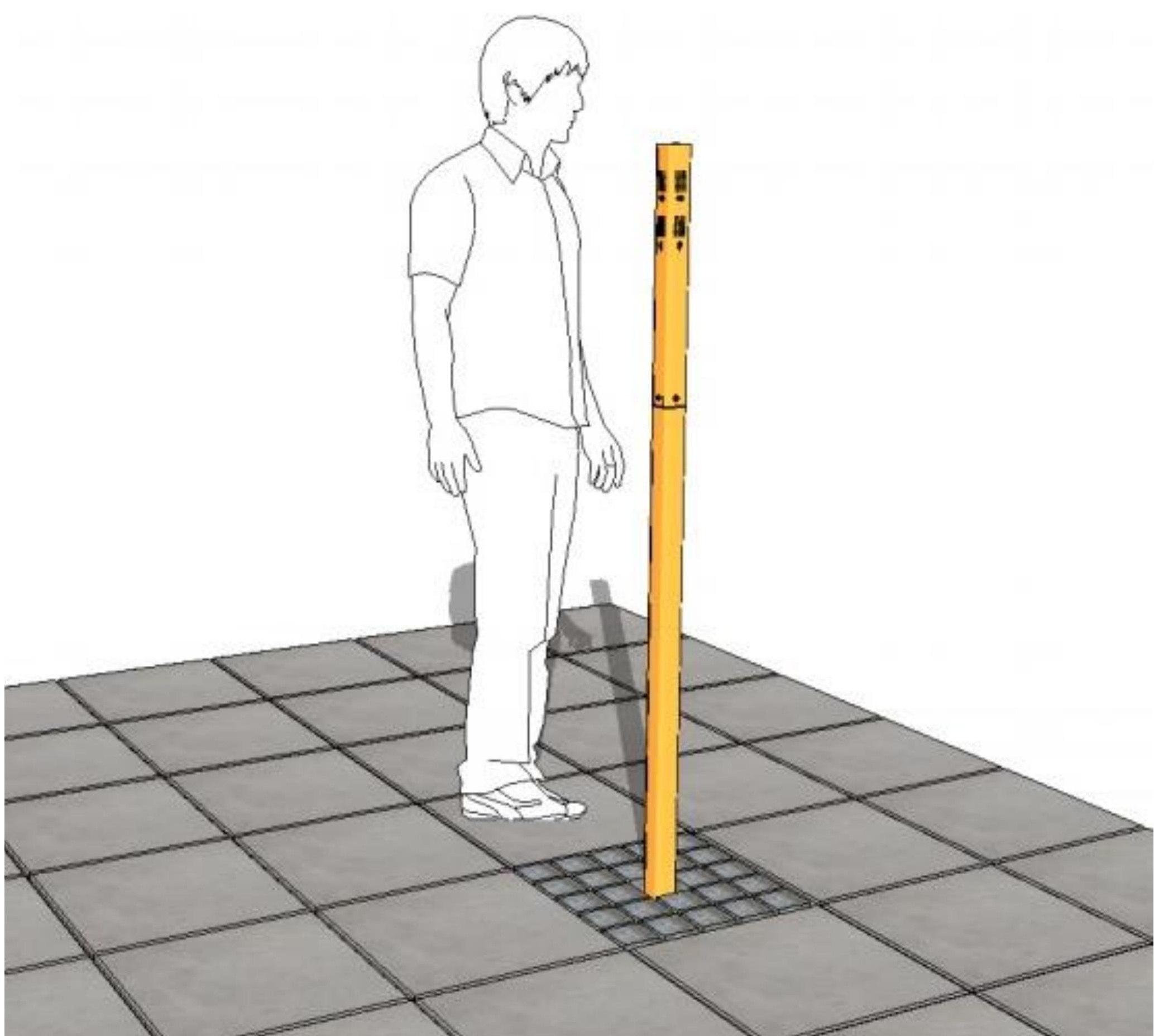


Denna sida har avsiktligt lämnats blank med hänsyn till dubbelsidig utskrift. 


\section{Sammanfattning}

Collective Communication är ett examensarbete som har gjorts i samarbete med examensarbetets uppdragsgivare, konstnären och arkitekten Robert Hais. Roberts vision var att skapa ett offentligt konstverk för att belysa alla människors lika värde oavsett kön, ålder, etnicitet, läggning etcetera, samt att belysa vikten av att prata med varandra i verkligheten och inte enbart via sms, facebook, snapchat och andra sociala medier.

Idén är en offentlig kommunikationsportal som ska vara placerad i olika städer och vara ihopkopplade inom samma nätverk. På så sätt ska människor som passerar konstverket i respektive stad kunna prata in ett meddelande som skickas vidare till ett annat konstverk i en annan stad där meddelandet spelas upp. Ingen vet vem som spelade in meddelandet eller vart det skickades ifrån. Mottagaren av meddelandet blir därmed troligen nyfiken och skickar iväg ett nytt meddelande som tas emot av ett annat av konstverken inom nätverket.

Studenternas uppgift i detta projekt har varit att agera projektledare för examensarbetet, vara med och ta beslut kring alla delar runt konstverket samt att få alla delar att fungera ihop. En version av konstverket har tagits fram som prototyp och ytterligare versioner av konstverket har för dess genomförande beskrivits med hjälp av handlingsplaner. 


\begin{abstract}
Collective Communication is a thesis that has been done in a cooperation with the employer of the project, the artist and architect Roberts Hais. Roberts vision was to create a public artwork to show that everyone is equal, no matter what gender, age, ethnicity or sexual orientation you have. He also wanted to show the meaning of talking to eachother in real life and not only via textmessaging, Facebook, Snapchat and other social medias.

The vision is to create a public communications portal that is supposed to be located in different cities but still connected to the same network. In this way someone that is passing by the artwork in one city can send a message to another artwork in a different city. In this way anonymous people can talk to eachother even though they're in different places.

The students task in this project has been project managers, participate and take decisions on all the components with the artworks and also making everything work together. One version of the artwork has been developed and further versions has been described in four different action plans.
\end{abstract}




\section{Förord}

Följande rapport är en slutgiltig sammanfattning av det examensarbete som har sträckt sig över höstterminen 2015 samt vårterminen 2016 på Högskolan i Halmstad. Examensarbetet har genomförts av två studenter på Utvecklingsingenjörsprogrammet och har varit ett samarbete med uppdragsgivaren Robert Hais.

Ett stort tack till Robert Hais, uppdragsgivare, för ett gott samarbete samt för ditt förtroende. Vi vill även passa på att rikta ett stort och betydande tack till vår handledare på Högskolan i Halmstad, Hans-Erik Eldemark, för all din stöttning samt engagemang under examensarbetets fortskridning.

Halmstad 2016

Anna Westberg

Emma Bäckman 


\section{Innehållsförteckning}

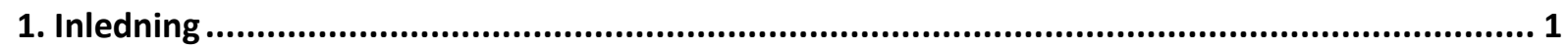

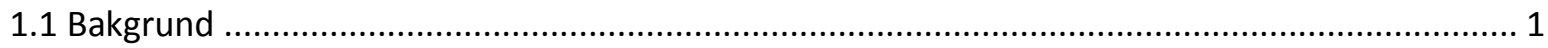

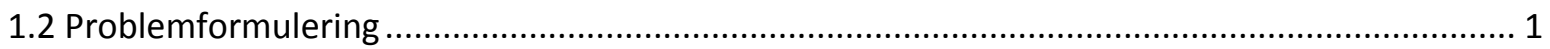

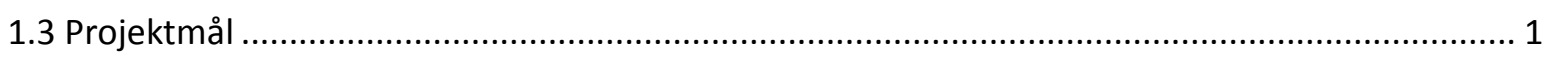



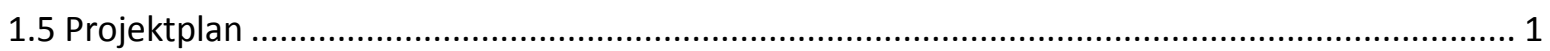

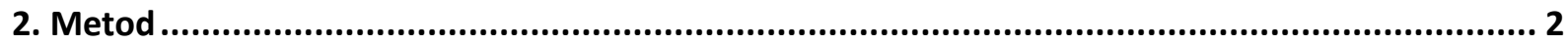

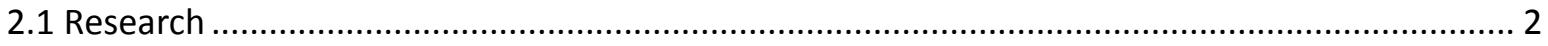



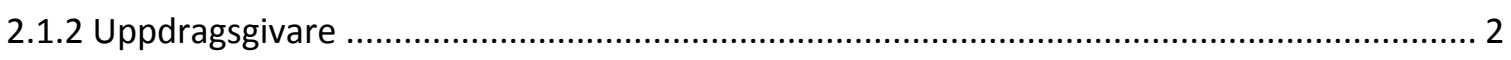

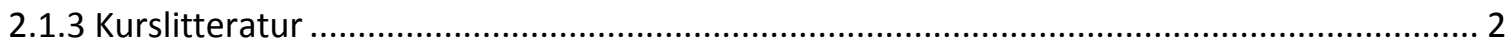

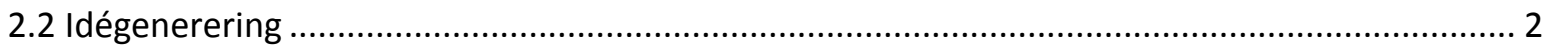

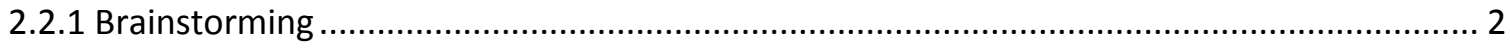

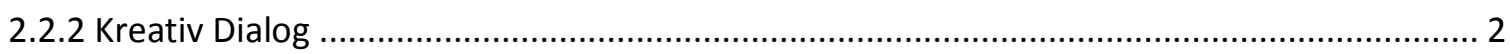

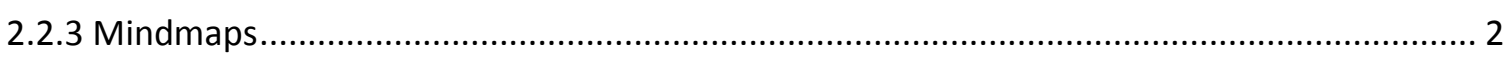

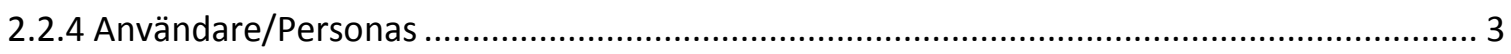

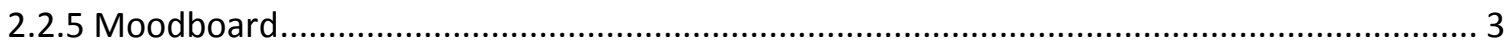

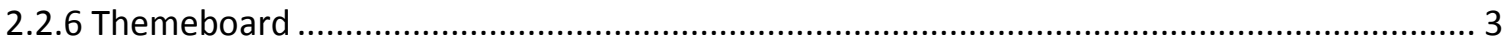

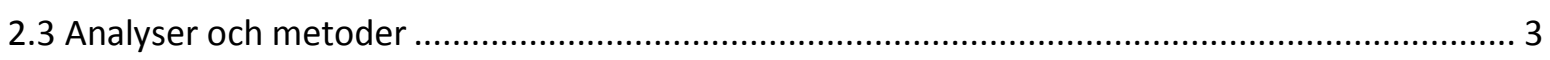

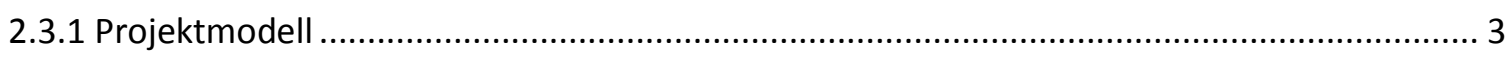

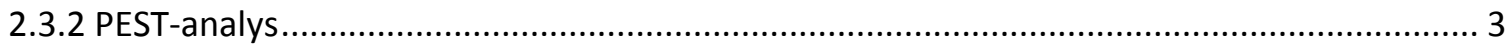

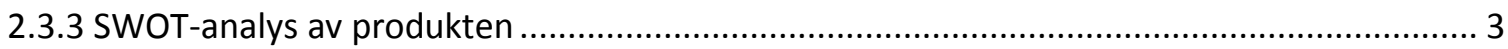

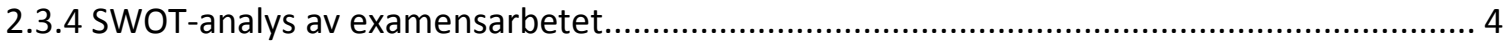

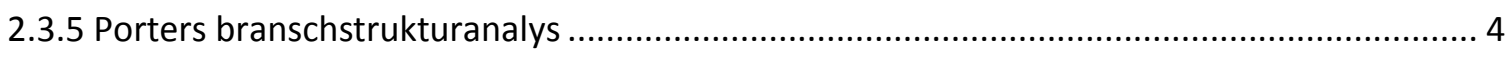

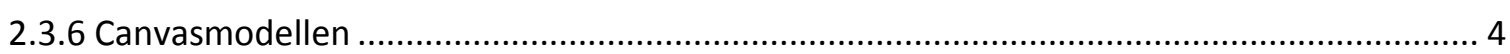

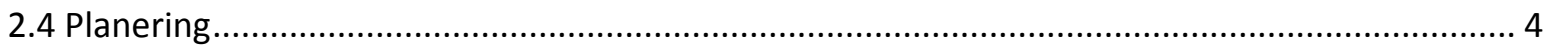

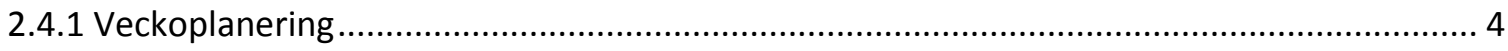

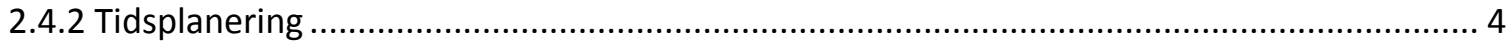

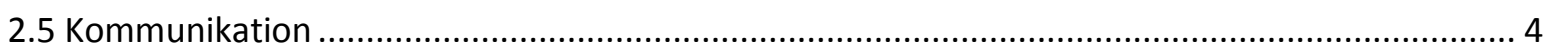

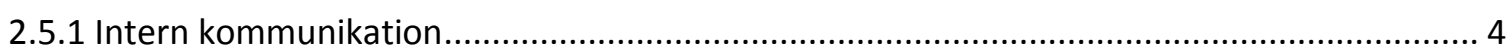



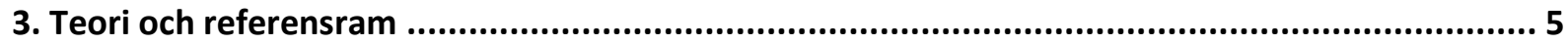



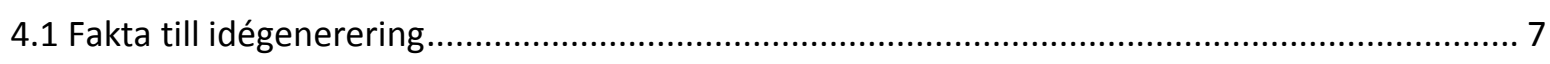

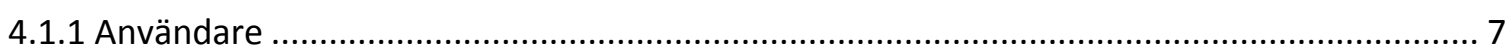

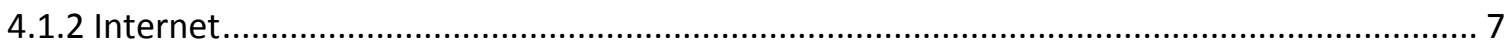




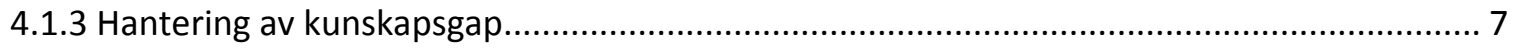

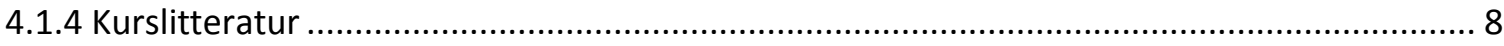



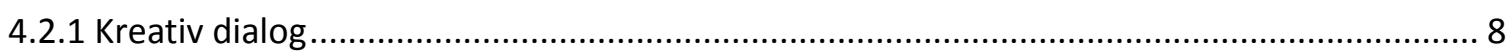



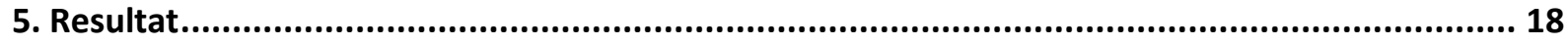

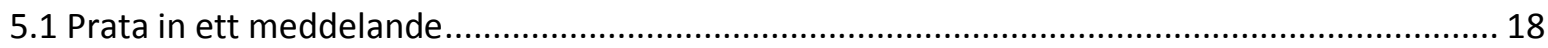

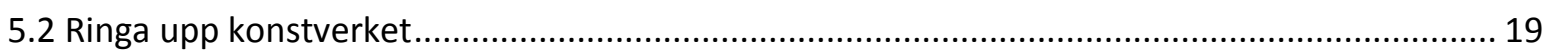

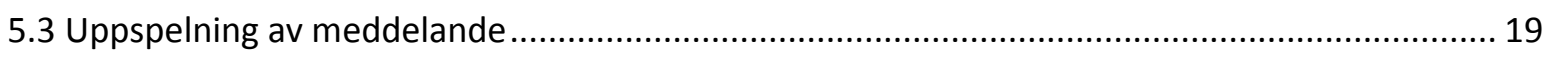





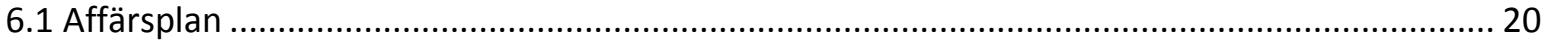

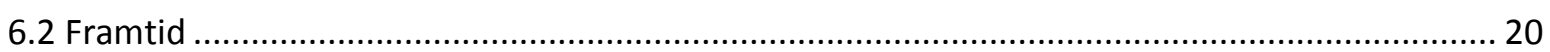

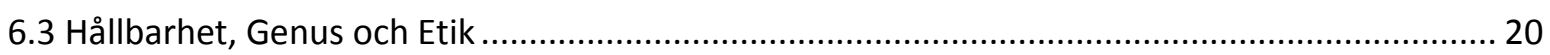

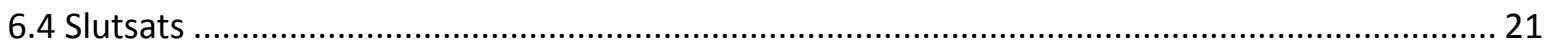



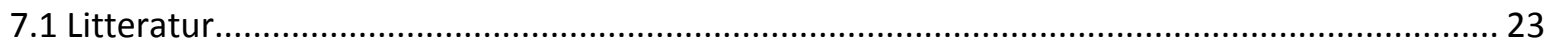





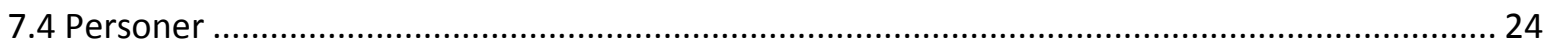

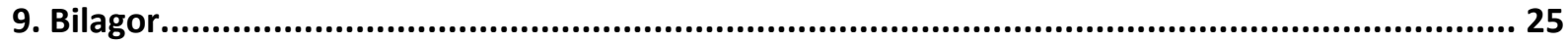




\section{Inledning}

\subsection{Bakgrund}

Uppdragsgivaren Robert Hais är konstnär och har bland annat tillverkat flera olika konstverk som finns att skåda på offentliga platser i Halmstad kommun. Gemensamt med många av hans verk är att de ofta har ett budskap bakom och så har även denna idé. Man kan se detta konstverk som en uppmaning till att prata med andra. Den ska sända ett budskap om att det inte spelar någon roll hur personer ser ut, hur gamla de är, vem de är kära i eller om de har något handikapp. Alla är lika mycket värda! Konstverket ger även budskapet om hur viktigt det är att kommunicera med varandra på riktigt och inte bara via sms eller en dator.

Examensarbetet utförs av två Utvecklingsingenjörsstudenter, Anna Westberg och Emma Bäckman och är ett samarbete med konstnären Robert Hais som även är uppdragsgivare.

\subsection{Problemformulering}

Vi lever idag i ett samhälle där kommunikation över internet och mobiltelefoner ökar. Det är inte längre självklart att prata med varandra i verkligheten utan ofta består konversationerna, speciellt för den yngre generationen, av sms och Facebook-chattande. Vi lever också i ett samhälle som i allt större utsträckning präglas av mobbning och utanförskap, till stor del via internet.

För att på ett roligt och annorlunda sätt visa att alla människor är lika värda oavsett kön, ålder, etnicitet eller sexuell läggning med mera är visionen att skapa en typ av offentlig kommunikationsportal. Detta är ett sorts socialt konstverk för att kommunicera med okända personer på offentliga platser.

För att skapa detta konstverk kommer det att krävas en mikrofon, högtalare, en fysisk gestaltning och ett sätt för konstverken att kommunicera med varandra.

\subsection{Projektmål}

Målet med examensarbetet är att leverera tre fullständiga prototyper av en kommunikationsportal som i framtiden ska finnas på offentliga platser. Förutom tre prototyper som ska kunna kommunicera med varandra ska det även finnas en rapport med såväl teoretiska och praktiska delar som analyser av nutidens trender gällande teknik etcetera.

\subsection{Effektmål}

Syftet med examensarbetet är utveckla en kommunikationsportal som ger användarna en annorlunda kommunikationsupplevelse genom att skicka meddelanden utan att lägga värderingar i vem mottagaren är. Förhoppningen är att resultatet leder till en eftertanke kring alla människors lika värde. Kommunikationsportalen är en konstnärlig produkt med målet att finnas på offentliga platser.

\subsection{Projektplan}

En projektplan innehållande projektorganisation, riskanalys, budget, intressentanalys, kravspecifikation, avgränsningar samt tidsplanering finns att läsa under Bilaga 1. 


\section{Metod}

I följande kapitel beskrivs det hur arbetet lagts upp samt de metoder som använts under examensarbetets gång.

\subsection{Research}

\subsubsection{Internet}

Internet är ett effektivt verktyg som kan användas vid bland annat insamling av information. Via sökmotorn Google har det sökts efter såväl olika komponenter till produkten men även efter information i allmänhet.

\subsubsection{Uppdragsgivare}

Värdefull information samt kontakter har erhållits via uppdragsgivaren Robert Hais. Möten med Robert har infallit ungefär varannan vecka på Roberts kontor, utöver möten har kommunikation främst skett via mail men även över telefon.

\subsubsection{Kurslitteratur}

För att säkerställa att rätt metoder används under examensarbetets gång och för att hitta tillförlitlig information har projektmedlemmarna använt sig av kurslitteratur från tidigare kurser på Utvecklingsingenjörprogrammet.

\subsection{Idégenerering}

\subsubsection{Brainstorming}

Brainstorming är en idégenereringsmetod som syftar till att hitta nya idéer eller att lösa olika problem. Detta sker i form av att en grupp sitter och diskuterar samt lägger fram olika idéer, där inga idéer kritiseras. Det uppmuntras till att vara spontan och våga berätta om sin idé. ${ }^{1}$

En lyckad brainstorming sker i tre steg, först idégenerering, sen idéförädling och sist prioritering och val. Idégenereringen går ut på att få ner alla idéer antingen nerskrivet på en dator eller uppsatta på till exempel en vägg, detta för att alla i gruppen ska få en bra överblick över idéerna och kunna inspireras av varandra. Nästa fas är idéförädling, där gruppen tar bort eventuella dubbletter samt bygger vidare på varandras idéer eller i vissa fall kombinerar flera idéer till en ny idé. Den sista fasen är prioritering och val, där gruppen filtrerar bort idéer och till slut kommer fram till det slutgiltiga resultatet. ${ }^{2}$

\subsubsection{Kreativ dialog}

En kreativ dialog sker i form av en diskussion mellan gruppmedlemmarna som sedan genererar i olika lösningar till ett problem. Detta bidrar till att medlemmarna kan få negativ och positiv feedback samt att gruppen kommer fram till många olika lösningar och därmed kan få ut bästa möjliga resultat. Skillnaden på en kreativ dialog och en vanlig dialog är att gruppen inte har aktivt avsatt en tid för diskussion. ${ }^{3}$

\subsubsection{Mindmaps}

Mindmaps är ett effektivt verktyg för att få en visuell överblick över vad som ska göras. Det är en typ av tankekarta där till exempel idéer kartläggs. Upplägget av en mindmap är att kärnan eller idén placeras i mitten av bilden och övriga ämnen eller faktorer som påverkar strålar ut från kärnan i form av "grenar".

\footnotetext{
${ }^{1}$ http://www.foreningsresursen.fi/foreningsarbete/metoder/brainstorming/ (hämtad 2016-03-29)

${ }^{2}$ Ibid

${ }^{3}$ Holmdahl, Lars; Lean Product Develompment På Svenska; 2010
} 


\subsubsection{Användare/Personas}

Personas används för att beskriva målgruppen för en produkt, utifrån beteende, intressen, kunskaper med mera. En persona är en fiktiv karaktär som tas fram av projektgruppen där personen beskrivs med namn, bilder och andra karaktärsdrag. Personas bidrar till att det blir enklare att förstå hur produkten ska utformas.

\subsubsection{Moodboard}

En Moodboard är en samling bilder i ett collage som på ett tydligt sätt beskriver känslan i produkten.

\subsubsection{Themeboard}

Themeboard är en samling bilder i ett collage som beskriver den känsla produkten ska utstråla med hjälp av dess material.

\subsection{Analyser och metoder}

\subsubsection{Projektmodell}



Figur 1 tagen från boken Projektledning, Bo Tonnquist.

Det finns olika projektmodeller att utgå ifrån och till detta examensarbete valdes modellen Project Base 2.0, se figur 1, som går att läsa om i kurslitteraturen Projektledning. ${ }^{4}$ I kombination med denna modell användes Dynamic Product Development vilket finns att läsa om i kurslitteraturen Dynamisk innovationsverksamhet. ${ }^{5}$ Examensarbetet har utgått från Dynamisk produktutveckling då detta främjar innovationsprojekt.

Till detta finns olika stöddokument som till exempel intressentanalys, kravspecifikation, riskanalys och projektbudget. Tidsplaner enligt modellen har gjorts och finns att läsa i Bilaga 7 och 8.

\subsubsection{PEST-analys}

PEST är en omvärldsanalys där möjligheter och hot analyseras ur olika aspekter. Aspekterna som analyseras är politiska, ekonomiska, sociala och tekniska och dessa kan ha både negativ och positiv inverkan på företaget. PEST resulterar sedan i att möjligheter och hot kan användas i en SWOT-analys.

\footnotetext{
${ }^{4}$ Tonnquist, Bo; Projektledning; 2014

${ }^{5}$ Ottosson Stig; Dynamisk innovationsverksamhet; 2012
} 


\subsubsection{SWOT-analys av produkten}

En SWOT-analys på produkten har gjorts för att belysa produktens styrkor och svagheter men även möjligheter och hot som framkommer efter PEST-analysen.

\subsubsection{SWOT-analys av examensarbetet}

En SWOT-analys av examensarbetet analyserar examensarbetets styrkor, svagheter, möjligheter och hot. Detta är ett bra sätt att förebygga framtida problem eftersom dessa då kan behandlas i tid. Det är även ett bra sätt för att ta reda på vad som är bra med examensarbetet och hur det ska kunna utvecklas framåt på bästa sätt.

\subsubsection{Porters branschstrukturanalys}

En branschstrukturanalys beskriver hur attraktivt det är att befinna sig i en bransch. Vid analysering av detta studeras fem olika krafter. Kunder, leverantörer, nya aktörer, substitut och konkurrenter. Är det ett högt tryck från dessa krafter minskar lönsamheten.

\subsubsection{Canvasmodellen}

Canvas är en modell som tillämpas för att kunna få en tydlig bild av företaget. Här visas bland annat vad företaget har för kundsegment, nyckeluppgifter och aktiviteter.

\subsection{Planering}

\subsubsection{Veckoplanering}

Varje måndag har projektgruppen gjort en veckoplanering där saker som ska göras under veckan listas upp samt vad som uppfyllts sedan den senaste veckoplaneringen.

\subsubsection{Tidsplanering}

Utöver veckoplaneringar har projektgruppen gjort två stycken tidsplaneringar i form av ett Gantt-schema, ett för respektive halvår. Ett Gantt-schema är en typ av flödesschema där olika aktiviteter ställs upp med dess start- och slutpunkt. Tidsplaneringarna finns i Bilaga 7 och 8 .

\subsection{Kommunikation}

\subsubsection{Intern kommunikation}

Examensarbetet har krävt mycket kommunikation inom både projektgruppen och mellan projektgrupp och uppdragsgivare. Internt har kommunikationen varierat mellan främst möten och telefonsamtal inom projektgruppen. Förutom det har en mapp på Google Drive skapats innehållande alla relevanta dokument för examensarbetet som båda medlemmar har tillgång till och en Facebookgrupp för att dela relevant innehåll i så som vad som ska göras i examensarbetet och deadlines.

\subsubsection{Extern kommunikation}

Externt har kommunikationen framförallt skett genom mailkontakt och möten, men även genom telefonsamtal. För projektmedlemmarna har examensarbetet till stor del inneburit en projektledarroll och därmed har uppgiften bland annat varit att hålla i kontaktnätet för examensarbetet. Därför har examensarbetet inneburit mycket kommunikation med olika parter.

Mellan projektgrupp och uppdragsgivare har kommunikation skett kontinuerligt genom både mailkontakt, telefonsamtal och möten. På så sätt har alla parter hela tiden kunnat hållas uppdaterade om hur examensarbetet fortskrider. 
Kommunikation mellan projektgrupp och handledare har främst skett genom mail och möten varje vecka.

\section{Teori och referensram}

Konst på offentliga platser är viktigt då det ger människan övning av sin estetiska och reflekterande förmåga i vardagen. Ett konstverk är ofta något som krävs att reflekteras över. Det är inget som alltid uppfattas som självklart av människan och det är därför något vi kan fundera över utan att vara medvetna om det. Offentlig konst bidrar också till trevligare och mer trivsamma miljöer att vistas på vilket motsträvar både vandalism och otrygga offentliga platser. ${ }^{6}$

Bryant Park i New York är ett exempel på detta. Parken var från början en otrygg plats där både droghandel och våldsbrott var vardag. Då valde den tidigare förvaltningschefen för parken att återuppliva den genom omdesign och ombyggnad. Detta resulterade i ett kulturellt centrum för både New York-bor och turister från hela världen. De skulpturer som pryder parken har fått beröm av både konstkritiker och parkbesökare och parken är idag känd för sin konst istället för kriminalitet. ${ }^{7}$

I USA har ett koncept som kallas " $1 \%$ of art" blivit stort inom både olika kommuner, län, stater, publika institutioner och universitet. Konceptet bygger på visuell konst som är offentligt finansierad och finns bland annat på olika universitetscampus, i gatuhörn, på reklampelare, på busshållplatser och i anslutning till motorvägar med mera. Vissa av dessa konstverk har genom detta koncept blivit kända, bland annat Cruisin' San Mateo av Barbara Grygutis i Albuquerque och Samson av Brian Goggin vid bagageutlämningen på Sacramentos flygplats nordost om San Francisco i Kalifornien. ${ }^{8}$

Genom detta koncept är dock många offentliga platser exkluderade. En flygplats innefattas av konceptet, men det gäller endast platsen för bagageutlämningen och inte till exempel kontrolltornet. Även privata kontor exkluderas av detta koncept. ${ }^{9}$

Alla konstnärer som gör offentliga konstverk har en möjlighet att både utmana och skapa en medvetenhet kring konst och utveckla människans kreativa sinne. Offentlig konst är med andra ord en viktig del av den civilisation vi lever $\mathrm{i}^{10}$

Detta projekt handlar om ett konstverk och är därför speciellt. Ett konstverk faller inte under samma lagar och regler som en vanlig produkt som ska säljas ute på marknaden. Kunden är i detta fall kommunen och konsument blir de besökare som rör sig på offentliga platser. I och med detta är kund och konsument inte samma sak. Så för att denna produkt ska kunna säljas och bli lyckad krävs att engagera båda parter.

Produkten syftar till en tillgänglighet som idag försvinner mer och mer i och med den allt mer datoriserade världen. Inom designvärlden finns ett begrepp som heter "design för alla" och som syftar till just detta. Att designen av en produkt ska ge den en tillgänglighet som krävs för

\footnotetext{
${ }^{6}$ Sussman Jeffrey; Art in public spaces; publicerad 23 juli 2013

${ }^{7}$ Ibid

${ }^{8}$ Ibid

${ }^{9}$ Ibid

10 Ibid
} 
att vem som helst ska kunna använda den oavsett ålder, kön, längd, etnicitet och så vidare. Det kan även handla om tillgänglighet i form av vart produkten ska placeras. Detta för att vara tillgänglig för både äldre, handikappade, barn och vuxna. "Design för alla" syftar till att säkerställa att den tekniska innovationen är knuten till sociala framsteg. ${ }^{11}$

En del av funktionen med en produkt är att den kommunicerar med användaren, men form, yta och utseende är det som viktigast definierar en produkt. Utöver det har även känslan en stor betydelse. Alla människans sinnen är viktiga att beakta när en ny produkt ska tillverkas. För att översätta detta till konstverket är det viktigt att se till det semantiska i produkten. Hur ska färg och form hänga ihop för att tillgängligheten ska bli så stor som möjligt? Hur ska användaren förstå hur produkten ska användas? Det krävs att produkten visar ett tydligt budskap eftersom målgruppen är otroligt bred. Komplexiteten får därför inte vara för hög och den ska stämma överens med de behov och den referensram som individen har. När det som i detta fall är en helt ny produkt som inte finns sedan tidigare är det extra viktigt med en naturlig utformning. ${ }^{12}$

Färg är en annan viktig del i utseendet av produkten. Färgen kan skicka signaler till användaren om hur den ska förhålla sig till produkten. Det är inget vi medvetet tänker på men det finns där naturligt. Rött är exempelvis en färg som signalerar fara, gult signalerar uppmärksamhet och grönt signalerar godkänt precis som rödljusen på vägarna visar. ${ }^{13}$

Som tidigare nämnts lyckas konstverk klara sig undan från en hel del skrivna och oskrivna lagar och regler som normalt gäller. Men för att produkten ska fungera för en så stor målgrupp krävs ändå att en hel del av det tänk som ligger till grund för designen av en produkt tas i beaktande även för detta konstverk.

\footnotetext{
${ }^{11}$ Persson, Åhman, Arvei Ynglin, Jan; Universal design, inclusive design, accessible design, design for all; publicerad 14 maj 2014

12 Österlin Kenneth; Design i fokus för produktutveckling; 2011

${ }^{13}$ Ibid
} 


\section{Genomförande}

\subsection{Fakta till idégenerering}

\subsubsection{Användare}

Då Collective Communication är ett offentligt konstverk är kunden och användaren inte samma person. Kunden är de som köper in konstverket, alltså kommunerna. Först måste konstverket därför säljas in till kommunerna för att de ska kunna tas i bruk på offentliga platser.

Användaren av produkten är de människor som passerar de platser där produkten finns tillgänglig och målgruppen är därför mycket bred. Då produkten ska finnas tillgänglig på offentliga platser är det viktigt att den passar alla. I detta fall är höjden det problem som kan försvåra tillgängligheten av konstverket och detta bör tas hänsyn till.

\subsubsection{Internet}

Som tidigare nämnt under avsnittet metod har internet använts flitigt. Internet har använts till att kommunicera med intressenter och även via Google Drive kunna spara viktiga dokument. Men främst har internet varit väldigt värdefullt vid sökandet av komponenter och mer kunskap. Idag finns det många internetsidor med svar på de frågor som kommer upp under examensarbetets gång och med hjälp av internet har bättre kunskap om teknik till olika komponenter ökats hos projektgruppen. För att få ut det bästa möjliga resultatet av en internetsökning är det viktigt att vara källkritisk och vara väldigt noga med att se över om den insamlade informationen är helt korrekt.

\subsubsection{Hantering av kunskapsgap}

I uppstarten av examensarbetet hade studenterna bristande kunskap gällande tekniken och alla de komponenter som behövs för att kunna tillverka en prototyp. För att kunna samla in kunskap på ett effektivt sätt har projektgruppen samt uppdragsgivaren Robert Hais varit på många möten med privatpersoner samt företag. EffectSoft, beläget i Halmstad, var ett av de företag som besöktes. EffectSoft är ett IT-företag som jobbar med bland annat mjukvaruutveckling. ${ }^{14}$ På mötet fick projektgruppen mer kunskap om hur det skulle fungera med ett så kallat moln, alltså en IT-tjänst, samt en bättre överblick över vad som krävs för att få tekniken att fungera. ${ }^{15}$

Erik Halvordsson på HMS har projektgruppen samt Robert haft ett möte med. Erik har agerat bollplank och delat med sig av sin kunskap och gett betydande råd i början av examensarbetet. Ett annat möte var med Staffan Karlsson, som är ljudtekniker och producent. Staffan var nere i verkstaden belägen i samma byggnad som Roberts kontor, för att se på konstverket och komma med feedback och input. Staffan gav mycket råd om vad som bör tänkas på gällande högtalare, hur de ska vinklas samt väldigt användbar input överlag. Daniel Petersson på Assisting Systems har även besökts av projektgruppen för hjälp med hur tekniken kan utformas. Daniel tog sig an både hård- och mjukvaran så den tjänsten köptes av honom på grund av otillräcklig kunskap gällande det området hos projektgruppen.

\footnotetext{
${ }^{14}$ http://www.effectsoft.se/om-oss-25731985 (hämtad 2016-03-15)

${ }^{15}$ https://sv.wikipedia.org/wiki/Datormoln (hämtad 2016-03-15)
} 
Förutom möten har projektgruppen varit i kontakt med bland annat Halmstad kommun gällande internetuppkoppling till konstverket, samt Hans Ripén som jobbar som elingenjör där, gällande eltillförsel. Ett urval av mötesanteckningar finns i Bilaga 12.

\subsubsection{Kurslitteratur}

Kurslitteraturen Design i fokus köptes in i samband med en designkurs och var i detta projekt användbar vid fastställandet av det semantiska uttrycket i konstverket. Det utgör tillsammans med olika vetenskapliga artiklar rubriken Teori och referensram. ${ }^{16}$

Projektledning av Bo Tonnquist och Dynamsik Innovationsverksamhet av Stig Ottosson användes vid fastställandet av den projektmodell som använts i examensarbetet. ${ }^{17}$

\subsection{Idégenerering}

\subsubsection{Kreativ dialog}

Kreativ dialog har i princip använts genom hela examensarbetet för att lösa olika problem.

Båda projektmedlemmarna har kommit med användbar input som har diskuterats tillsammans. Det viktigaste och mest användbara som kommit ut av detta har sedan tagits vidare för ytterligare diskussioner och samråd med uppdragsgivare.

\subsubsection{Brainstorming}

\section{Överblick}

I starten av examensarbetet var det många oklarheter kring vad som behövde tas reda på och vad som skulle göras i examensarbetet då det var många olika delar av konstverket och komponenter att ta hänsyn till. Projektgruppen gjorde därför mindmaps för varje del av konstverket för att enkelt kunna få en bra överblick över alla moment som behövde göras och tänkas igenom. Alla mindmaps presenteras i Bilaga 6.

\section{Kundsegment}

I ett tidigt stadie av examensarbetet valde projektgruppen att göra två personas. Detta för att få en tydlig bild över målgruppen för Collective Communication men även för övriga intressenter som vill bli mer bekanta med målgruppen. Personas gjordes gemensamt i projektgruppen där det valdes två olika åldersgrupper, kön och intressen för att påvisa bredden av användare för Collective Communication. Båda personas finns i Bilaga 11.

Projektgruppen gjorde research efter olika bilder som tillsammans beskriver känslan produkten utstrålar. Orden "glad", "kärlek", "tillgänglig" och "nyfiken" utgjorde grunden för de bilder som valdes. Moodboarden ligger till grund för det uttryck som produkten ska förmedla vid första anblick.

Det genomgående temat för denna Moodboard är bilder med människor som beskriver dessa känslor. Anledningen till att projektgruppen valde bilder med enbart människor är på grund av att det stämmer väl överens med produktens bakomliggande tanke, att förena människor.

Moodboarden finns i Bilaga 9.

\footnotetext{
${ }^{16}$ Ibid, sid. 5,6

${ }^{17}$ Ibid, sid. 3
} 


\section{Collective Communication}

Vid examensarbetets uppstart hade uppdragsgivaren Robert Hais en tydlig bild av hur konstverket skulle se ut. Detta innefattar utseende, färg samt design av hålformationer och symboler.

Det finns rimliga förklaringar till varför konstverket har sitt utseende vilket till stor del är förankrat i semantiska uttryck och konstnärliga aspekter. Konstverket kommer att gestaltas i form av en stolpe. Storleksmässigt är stolpens yttermått 50x50 mm vilket ger konstverket ett relativt smalt intryck på ett längre avstånd. Diskussionerna kring detta har resulterat $\mathrm{i}$ att en bredare dimension av stolpen skulle ge ett klumpigt intryck vilket inte eftersträvas i denna produkt. På håll ska konstverket ge förbipasserande en tankeställare så som konstverk ofta gör. Det som är annorlunda med detta konstverk är dock att den mer syftar till användningen av konstverket än till dess utseende. Det enda egentligen utmärkande är dess gula färg som semantiskt uttryckt syftar till att uppmärksamma förbipasserande.

Hålformationerna för mikrofon och högtalare har endast en utseendemässig betydelse. Det är $5 \times 8$ hål på varje sida av stolpen med en diameter på $3 \mathrm{~mm}$, för högtalaren och för mikrofonen. Den stora svårigheten med konstverket som påverkar dess utseende är att den ska stå på en offentlig plats och därmed vara tillgängliga för alla. Detta innebär att alla människor oavsett längd eller funktionshinder ska kunna använda konstverket. Här har tre olika alternativ funnits. Två stolpar i olika höjd bredvid varandra, en stolpe som på något sätt ska kunna regleras i olika höjd eller en stolpe som har en medelhöjd.

Projektgruppen hade i början funderingar på om det skulle vara möjligt att ha två stolpar bredvid varandra i två olika höjder. Detta för att kunna anpassa ett konstverk i två medelhöjder. Nackdelen med detta är att det förstör det estetiska uttrycket i konstverket och det kan även bli problem med de tekniska delarna. De två stolparna måste i detta fall både kunna kommunicera med varandra och med resten av stolparna i nätverket. Det kan dessutom vara svårt att få stolparna att förstå vilken av dem som ska motta och sända meddelandena så att det inte blir ett halvt meddelande från var konstverk som spelas upp eller skickas iväg.

Brainstormingen utvecklades därefter till enbart ett konstverk som istället ska kunna regleras i höjd, på liknande sätt som ett teleskopskaft fungerar. Enda fördelen med detta är att konstverket kan ha olika höjder beroende på vem som ska prata in ett meddelande. Idén skrotades dock snabbt för att den dels skulle påverka utseendet och dels är för komplicerad att tillverka och montera ihop.

Kvar fanns idén om ett konstverk i en medelhöjd som ska kunna passa så många som möjligt. Projektgruppen har testat sig fram till att en höjd på 150 centimeter över marken då det anses utgöra ett lagom höjdläge för de flesta. Många vuxna personer kommer att få böja sig ner för att komma i rätt höjd till mikrofon och högtalare men projektgruppen har resonerat att det är bättre att böja sig ner än att inte nå upp tillräckligt.

Efter brainstorming och tester blev resultatet det sistnämnda konceptet vilket beskrivs mer under kapitel 5.

\section{Materialval}

Precis som till moodboarden gjordes research efter olika bilder. Till themeboarden skulle bilderna istället beskriva känslan i produktens material. Grunden för dessa bilder utgjordes av orden "hårt", "stål", "betong" och "elektricitet" som enligt projektgruppen är ord som väl 
beskriver produktens material och den känsla de ska utstråla.

I början av examensarbetet hade uppdragsgivaren Robert Hais redan bestämt material till konstverket. Materialet som valts är varmformade konstruktionsrör i form av fyrkantsrör. Konstverket kommer att skyddas med tjockfilmspassificering då det är det bästa skyddet både ut- och invändigt. Därefter kommer konstverket att våtlackeras och sedan kommer hål etcetera att borras. Företaget som kommer att tillverka konstverket är Östras Stålprodukter AB, som är beläget i Osby och är en kontakt som Robert har sedan tidigare.

Projektgruppen har undersökt andra materialalternativ så som till exempel rostfritt stål. Rostfritt stål hade varit en fördel då det eventuellt hade kunnat bidra till att våtlackering inte behövs och därmed hade den kostnaden undvikits. Även ur rostsynpunkt hade det varit en fördel. Dock valde uppdragsgivaren i uppstarten av examensarbetet att välja bort detta material på grund av kostnadsfrågor. ${ }^{18,19,20,21}$

\section{Fastsättning av symboler}

För att användaren ska förstå hur produkten ska användas krävs symboler som beskriver detta. Det kommer att krävas en symbol för högtalaren och en för mikrofonen som ska finnas på alla fyra sidor av konstverket, under respektive hålformation.

Projektgruppen har haft olika funderingar på hur symbolerna ska fästas på konstverket för att de ska klara av både väderförhållanden och sabotage så bra som möjligt. Brainstorming kring detta resulterade i ett första förslag som var att gravera in symbolerna i konstverket. Detta skulle hålla mönstret på plats men det krävs att graveringen fylls i med svart färg för att synas. Detta medför försämrad hållbarhet av symbolerna då färgen lätt kommer att utsättas för slitage. Dessutom är symbolerna relativt små och det är svårt att få graveringen snyggt gjord.

Nästa alternativ som framkom av brainstormingen var symboler gjorda i gummi som limmas fast på utsidan. Detta alternativ gick också bort då fastklistrade symboler lätt kan släppa i limmet och det ökar också risken för sabotage då de är lätta att lösgöra.

Projektgruppen har funderat på ytterligare förslag som att använda en schablonmall och spraylacka på symbolerna. Nackdelen med detta förslag är att det lätt kan skrapas bort och därmed fallerar även det förslaget.

Slutligen har projektgruppen i samråd med uppdragsgivaren kommit fram till att testa med någon form av laminering likt det som finns på skyltar och företagsreklam på bilar med mera. I samband med att testserien av stolparna görs angående tekniken kommer även symbolerna att utvärderas för att se på hållbarheten i detta alternativ. Om det inte fungerar bra får ett nytt förslag tas fram då, men det är i dagsläget det bästa alternativ som finns.

\section{Låsning}

En viktig del vid utformningen av konstverket är att tekniken på ett enkelt och smidigt sätt ska kunna lyftas ur vid behov av service. Det finns många olika aspekter att ta hänsyn till, bland

\footnotetext{
${ }^{18} \mathrm{http}: / /$ sbi.se/uploads/source/files/Artiklar/Rosttroga_stal_rev20150226.pdf (hämtad 2016-03-27)

${ }^{19} \mathrm{http} / / / \mathrm{sbi}$. se/uploads/source/files/Artiklar/Stalets_egenskaper.pdf (hämtad 2016-03-27)

${ }^{20} \mathrm{http}$ ://www.begroup.com/sv/BE-Group-sverige/Produkter/Rostfritt/Produktinformation/Om-rostfritt-stal/ (hämtad 2016-03-27)
} 
annat att låsningen samt delen som man lyfter bort ska vara estetiskt tilltalande samt vara fastsatt ordentligt för att undvika vandalism. Projektgruppen och uppdragsgivaren har kollat på olika förslag på detta som presenteras nedan.

\section{Alternativ 1}

Det första förslaget presenteras på bilden nedan till vänster. Tanken är att man på ett enkelt sätt ska kunna lyfta ur den övre delen där tekniken ska vara placerad, för att sedan kunna byta ut den del som till exempel är trasig. Sedan sätter man tillbaka den övre delen och låser fast den. Se Bild 1.

\section{Alternativ 2}

Det andra förslaget innefattar också att man lyfter bort den övre delen, men på insidan sitter fyra varmformade konstruktionsrör för stabilitet och för att motverka vandalism på ett bra sätt. Tanken är då att tekniken ska vara fastsatt mellan de fyra rundstålen, så man på liknande sätt som alternativ 1 kan utföra service och sedan sätta på den övre delen igen. Förslaget presenteras nedan, se Bild 2.

Alternativ 2 var det förslag som valdes eftersom det bidrar till mer stabilitet än det första förslaget men det har ändå samma uppbyggnad för tekniken som i alternativ 1 .

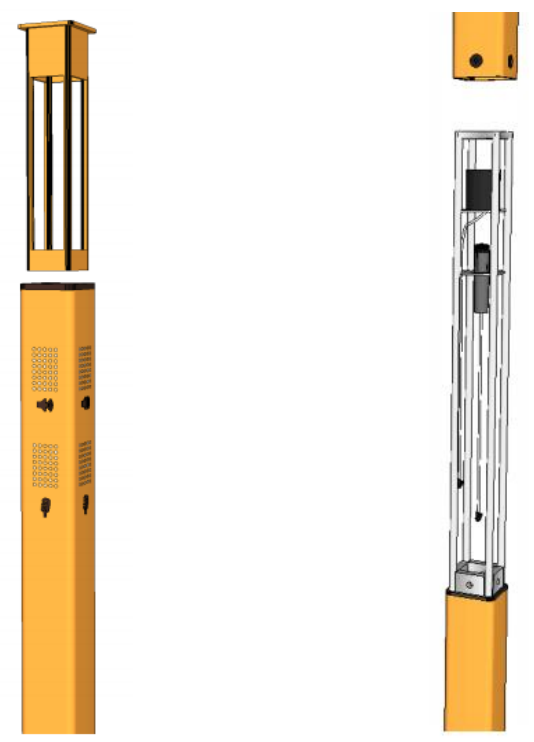

Bild 1 och 2, gjorda av Robert Hais

Bilderna visar de olika alternativ som diskuterats fram kring låsning av servicedelen.

För att kunna låsa den övre delen har flera förslag ställts mot varandra. Ett av förslagen var att ha en vanlig låsmekanism, men detta valdes bort på grund av att det tog mycket plats på insidan av konstverket.

Det andra förslaget var fyra skruvar på vardera sida och för att undvika vandalism så mycket det går valdes det att kolla på säkerhetsskruvar. Säkerhetsskruvar behöver ett speciellt verktyg för att kunna skruvas upp, medan de flesta vanliga skruvar kräver en insexnyckel som är ett vanligare verktyg de flesta har hemma. Först hittades en säkerhetsskruv som hade ett utstickande huvud, vilket inte var estetiskt tilltalande. Därför började projektgruppen att kolla efter säkerhetsskruvar som är försänkta för att de enklare ska smälta in i designen. Försänkta säkerhetsskruvar med rostfri A2-70 kvalitet, fanns på Würth's hemsida och är de skruvar som 
kommer att användas i examensarbetet. ${ }^{22}$ En bild på hur säkerhetsskruven ser ut presenteras i Bild 3.



Bild 3, Säkerhetsskruv

\section{Fastsättning}

Tidigt under examensarbetets start var projektgruppen inne på hur cykelställ sätts fast i marken. Kommunen kontaktades för att ta reda på mer information gällande fastsättningen av cykelställ, men detta jobbade projektgruppen inte vidare med då det i samråd med uppdragsgivaren bestämdes att en betongplint skulle användas för fastsättningen. För att sätta fast konstverket i marken kommer ett företag behöva anlitas för att gräva ett hål i marken. Tanken är sen att betongplinten förs ner i hålet, sedan täcks den med sand och ovanpå sanden läggs eventuellt plattor eller stenar. Detta bidrar till att konstverket blir svårare att rubba och därmed blir det starkare mot vandalism.

\section{Teknik}

I början av vårterminen lades mycket tid på att göra research kring tekniken. Projektgruppen har läst en grundkurs inom datorteknik samt en grundkurs inom elektroteknik men det är den enda kunskap de besitter. Projektgruppen har tidigare jobbat med Arduino, som är ett mikrokontrollerkort och användes både i kursen datorteknik och elektroteknik. För att ta reda på om Arduino var passande för denna typ av teknik gjordes research med hjälp av internet och sökmotorn Google.

Förutom Arduino hittade projektgruppen även två andra alternativ, Raspberry Pi och TinyDuino. ${ }^{23,24}$ TinyDuino fungerar på liknande sätt som en Arduino, men till storleken av en enkrona vilket var en stor fördel då utrymmet i konstverket inte är stort. Raspberry Pi är en enkortsdator och har bättre dokumentation än Arduino, vilket resulterade i att projektgruppen valde att använda sig av en Raspberry Pi. Raspberry Pi finns i flera olika modeller, RPI Amodell, B-modell samt Zero. Projektgruppen valde att fördjupa sig i B-modellen då det är en nyare modell som har bättre anslutningsmöjligheter än A-modellen, samt Raspberry Pi Zero som är ett bättre alternativ storleksmässigt. ${ }^{25,26}$ Fördelen med RPI Zero är att datorn är väldigt liten och lätt kan få plats i konstverket, dock har inte modellen några anslutningsmöjligheter. Detta resulterade i att projektgruppen tyckte att B-modellen kändes mest lämpad för examensarbetet då internet kommer att behövas och den modellen har en ethernetanslutning.

\footnotetext{
${ }^{22} \mathrm{https} / / / \mathrm{www}$. wurth.se/produkter/fastmaterial/sakerhetsskruvar--tillbehor/platskruvar/sakerhetsskruv-forsankthuvud/sakerhetsskruv-ftxp/ (hämtad 2016-05-06)

${ }^{23} \mathrm{http}$ ://www.sweclockers.com/forum/trad/1334344-rasberry-pi-eller-arduino-vad-ar-skillnaden (hämtad 201602-29)

${ }^{24}$ https://www.tiny-circuits.com/products/tiny-duino.html (hämtad 2016-02-29)

${ }^{25} \mathrm{http}: / /$ www.kjell.com/se/fraga-kjell/teman/raspberry-pi (hämtad 2016-02-29)

${ }^{26} \mathrm{http} / / / \mathrm{www}$. conrad.se/?websale8=conradswe\&pi=1406729\&ws_tp1=cp\&ref=PLA_KOMPONENTER\&subref=1406729\&utm_source=PLA_KOMPON ENTER\&utm_medium=PLAfeed\&utm_campaign=PLA_KOMPONENTER_feed\&utm_content=1406729\&gcli d=Cj0KEQiArou2BRDcoN_c6NDI3oMBEiQANeix5ggkeNFGGp_TZ4mYg25-sCCd-

aVudi3hkIknopWQfPkaAp5r8P8HAQ (hämtad 2016-02-29)
} 
Research kring vad för typ av högtalare samt mikrofon som behövs gjordes också. I början var det svårt att hitta lämpliga internetsidor eftersom komponenterna bör vara minimala $\mathrm{i}$ jämförelse med de flesta portabla produkterna som idag används av privatpersoner. Sidan Electrokit hittades, där det fanns ett bra utbud av högtalare, mikrofoner samt övriga tillbehör som krävs vid liknande projekt. ${ }^{27}$ Här fann projektgruppen en del olika förslag som presenterades för uppdragsgivaren. ${ }^{28,29,30,31,32,33}$ För att få ytterligare information och kunskap kring detta området planerades det in ett möte med Staffan Karlsson som nämnts tidigare under kapitlet metod. Staffan är ljudtekniker och producent och hade till mötet tagit fram förslag på olika högtalare och mikrofoner, liknande de förslag projektgruppen hade kommit med, vilket påvisade att projektgruppen var inne på rätt spår.

Det sista steget var att hitta någon som skulle kunna hjälpa till med programmeringen. Projektgruppen hade nu gjort ordentlig research kring enkortsdatorer, högtalare samt mikrofon men har inte tillräcklig med kunskap för att kunna programmera samt sätta ihop tekniken själva. Via projektgruppens handledare, Hans-Erik Eldemark, fick projektgruppen kontaktuppgifter till Daniel Petersson på AssistingSystems, som tidigare jobbat med examensarbeten för Utvecklingsingenjörsprogrammet. Daniel kontaktades där man beskrev examensarbetet samt problemet och undrade om han var intresserad av att boka in ett möte för ytterligare information. Mötet blev av och projektgruppen presenterade examensarbetet samt den research de gjort. Daniel blev intresserad av examensarbetet och sa att han kunde ta sig an både hård- och mjukvaran för Collective Communication. Vissa av de komponenter som projektgruppen presenterade hade Daniel tidigare jobbat med vilket återigen tyder på att den research som gjorts var väl genomförd. Daniel kom så småningom med en egen idé på hur tekniken skulle utformas och det är den idén projektgruppen har valt att jobba vidare med samt kommer vara den som används vid prototypbygget. Mer ingående information kring idén finns under kapitel 5.

\section{Sensor/knapp}

Det måste finnas en början och ett avslut på meddelanden som pratas in i konstverket. Detta kan vara genom antingen en knapp som trycks in när en person ska prata in ett meddelande eller en sensor som känner av ljud på ett visst avstånd och därmed börjar spela in ett meddelande. Med en knappfunktion är fördelen att det blir enklare ur programmeringssynpunkt då meddelandet får en tydlig början och ett tydligt avslut. Detta ger dock en extra utsmyckning på konstverket vilken kan förstöra dess utseende. Dessutom är det en funktion som kan gå sönder genom antingen vandalisering eller hög användning och det kan vara svårt att förstå hur knappen ska användas för att spela in meddelandet. Alltså om knappen ska hållas in under hela tiden som samtalet ska pratas in eller om knappen både ska tryckas in och ut innan meddelandet spelas in.

Därmed har projektgruppen bestämt sig för att en sensor är bästa alternativet då det finns mest fördelar med detta. Det blir något mer komplicerat ur programmeringssynpunkt men inte märkvärt mycket mer. Genom detta får konstverket dessutom kvar sitt vanliga utseende, det finns inga funktioner som kan gå sönder för att någon använder den för mycket och det kan

\footnotetext{
${ }^{27} \mathrm{http}: / /$ www.electrokit.com/ (hämtad 2016-02-29)

${ }^{28} \mathrm{http} / / / \mathrm{www}$.electrokit.com/miniatyrhogtalare-o25mm-8ohm-3w.52371 (hämtad 2016-02-29)

${ }^{29} \mathrm{http}: / / \mathrm{www} . e l e c t r o k i t . c o m / h o g t a l a r e-8 \mathrm{ohm}-\mathrm{o} 21 \mathrm{~mm}-0-1 \mathrm{w} .41741$ (hämtad 2016-02-29)

${ }^{30} \mathrm{http}: / / \mathrm{www}$. electrokit.com/hogtalare-8ohm-o30mm-0-2w-pcb.49568 (hämtad 2016-02-29)

${ }^{31} \mathrm{http}: / / \mathrm{www}$. electrokit.com/hogtalare-8ohm-o40mm-0-25w-tunn.48834 (hämtad 2016-02-29)

${ }^{32} \mathrm{http}: / / \mathrm{www}$.electrokit.com/hogtalare-8ohm-o40mm-0-25w-tunn.48834 (hämtad 2016-02-29)

${ }^{33} \mathrm{http} / / / \mathrm{www}$.electrokit.com/electret-mikrofon-o9-7-x-6-7mm.43370 (hämtad 2016-02-29)
} 
inte bli missförstånd för användaren i hur den ska användas då det styrs utom dennes kontroll.

Högtalare

För att veta hur högt ljudet i konstverket ska vara för att det ska höras på ett lagom avstånd har projektgruppen med hjälp av en mobilhögtalare testat detta i utomhusmiljö.

Projektmedlemmarna har bestämt att ljudet från konstverket måste höras bra i en radie av 2 meter runt konstverket då detta anses vara ett lagom avstånd. Därför har en motsvarighet av detta iscensatts för att testas utomhus vilket går att läsa mer om under kapitel 4, underrubrik Tester.

En annan del att ta i beaktande vad gäller högtalare är hur den ska sitta i konstverket för att ge bästa ljud ut. En högtalare sprider ljud bäst åt ett håll och med tanke på att konstverket har möjlighet att sprida det åt fyra håll är tanken att vinkla två högtalare åt två håll. Därmed ska ljudet spridas bättre.

\section{Solceller}

Efter mötet med Daniel bestämdes det i samråd med Robert och Daniel att en solcell också skulle vara en del av prototypen. Anledningen till detta grundar sig i att det kommer att finnas ett batteripaket som innefattar ett standardbatteri och ett uppladdningsbart batteri. En solcell skulle därför medföra att man sparar på det uppladdningsbara batteriet under dagtid när det är ljust ute, så förhoppningsvis kan det uppladdningsbara batteriet laddas upp under dagen samt användas när det mörknar. Solcellen kommer att fästas på toppen av konstverket, i en nedförsänkning för att den inte ska sticka upp ovanför konstverket och förstöra det semantiska uttrycket, men även för att undvika förstörelse.

Nästa steg för projektgruppen och även för Daniel var att söka på internet efter lämpliga solceller. I början var det en del komplikationer på grund av att solcellerna som eftersöktes skulle vara cirka $42 \times 42 \mathrm{~mm}$ i storlek, vilket är väldigt litet. Efter internetsökningar hittade projektgruppen olika solceller på Ebay där en solcell på 2.0 Volt och en storlek på $40 x 40 \mathrm{~mm}$ kändes mest lämplig. Solcellen bifogades till Daniel som återkom med att det var för lite Volt då det behövdes 5.0 Volt. Daniel bifogade även alternativ från några standardleverantörer som hans företag brukar beställa ifrån och alla parter bestämde sig för att använda sig av en av dessa. Anledningen till detta beslut är att det är väldigt svårt att avgöra leveranstiden när man beställer från Ebay och att det är svårt att veta vad man får. Samt att Daniels företag beställt från dessa leverantörer tidigare vilket minskar risken för ytterligare komplikationer.

\section{Fukt}

Ett av de största frågetecknen i detta projekt är hur konstverket ska kunna göras fuktsäker med tanke på den teknik som ska finnas inuti. Konstverket ska befinna sig utomhus året om vilket innebär att den kommer utsättas för både fukt och väta. Det finns många scenarion att ta $i$ beaktande så som hällregn, att någon medvetet häller vätska genom hålformationerna eller att det är hög luftfuktighet utomhus.

Genom brainstorming började projektgruppen fundera på om det bästa alternativet är om det är tekniken eller insidan av konstverket som ska kläs in i ett material. Om tekniken kläs in finns risken att det blir för varmt inuti vilket gör det brandfarligt, men det är enklare att hålla tätt kring tekniken med denna lösning. Om konstverkets insida istället kläs in finns det mer utrymme för tekniken att ventileras men samtidigt finns också risken att fukt ändå kan tränga in. 
Det mest ultimata hade varit att till exempel omsluta tekniken med en plastburk likt det som finns för att t.ex. gopro-kameror eller enkortsdatorer ska bli vattentäta. Detta fungerar dock inte på detta konstverk på grund av dess storlek.

Projektgruppen har därmed brainstormat vidare och kommit fram till att någon form av tyg skulle kunna vara passande. Här har funderingar kring både tyg med goretexmaterial och markisväv tagits i beaktande. Goretex är egentligen ett produktnamn och inte ett tyg som säljs i metervara. ${ }^{34}$ Därför är det inte lösbart till detta projekt. Det alternativ som därmed fungerar bäst är markisväv som i ett antal olika varianter har testats under rinnande vatten.

Av företaget Fönsterinredarna i Halmstad mottogs tre olika testbitar av markisväv som sedan ska sys till en hätta som ska fästas i servicedelen av konstverket. ${ }^{35}$ Det första tyget var en grön markisväv av företaget Sandatex. Nackdelen med detta tyg är dock att det är för tjockt för att passa i konstverket. Trots att det klarade väta bra fungerar tyget alltså inte på grund av dess tjocklek. Det andra materialet projektgruppen fick möjlighet att testa är en vitbeige fritidsväv av företaget Nevotex som inte är ytbehandlad. Detta visade sig vara en nackdel då tyget inte klarade av väta. I kombination med att även detta tyg visade sig vara för tjockt valdes det också bort. Kvar att testa var då ett blått tyg, också det från Nevotex, som har en silikonbehandlad yta på ena sidan. Detta tyg passade bäst för ändamålet då det både är vattenresistent och tunt så att det får plats i konstverket.

\section{Tester}

Olika tester har gjorts under examensarbetets gång för att konstatera vilken lösning som fungerar mest optimalt. Ett av testen var ett materialtest för att undersöka vilket av de material som mottogs från Fönsterinredarna som var mest lämpligt för prototypen. Testet gick ut på att hålla materialen under vatten, se Bild 4, för att se om vattnet gick igenom tyget samt om det avdunstade, se Bild 5. Nedan syns bilder från testet.
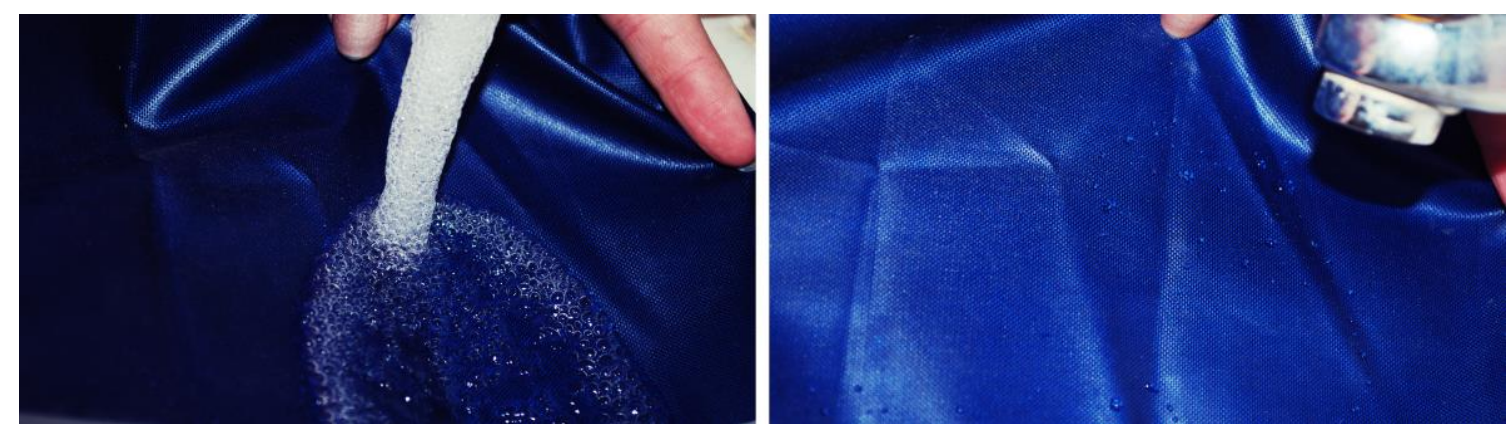

Bilden 4 är tagen under testet och Bild 5 påvisar att vattnet inte absorberats.

Det andra testet som gjorts är ett högtalartest för att undersöka hur högt högtalaren låter i en utomhusmiljö. För att få ett så verklighetstroget test som möjligt var projektgruppen i verkstaden på Högskolan i Halmstad och valde en rektangulär stålprofil som var $3 \mathrm{~mm}$ tjockt, alltså $1 \mathrm{~mm}$ tunnare än konstverket som används i examensarbetet. Stålprofilen hade inga hålformationer men hade öppna kortsidor vilket ungefär motsvarar hålformationerna på konstverket. Utöver stålröret använde sig projektgruppen även av materialet som valts att ha

\footnotetext{
${ }^{34}$ http://www.gore-tex.com/en-us/technology/what-is-gore-tex (hämtad 2016-04-12)

${ }^{35} \mathrm{http}: / /$ www.fonsterinredarna.se (hämtad 2016-04-12)
} 
på insidan av konstverket och ha en mobiltelefon inkapslad i detta material. Eftersom konstverket ska placeras i utomhusmiljö valdes det att genomföra testet på Laholmsvägen i Halmstad när det regnade samt bilar åkte förbi för att få en verklighetstrogen situation. Miljön för det testet har troligen högre bullernivå än i centrum där konstverket är tänkt att placeras, men projektgruppen valde att utföra testet ändå. Den ena studenten stod på trottoaren längs med Laholmsvägen och den andra stod två meter bort och ringde till telefonen inuti stålprofilen i omgångar. Telefonen inuti konstverket var på högsta volym då projektgruppen har kommit fram till att det är en lämplig ljudvolym. Anledningen till att det inte valdes att sätta på musik eller ringa konstant är för att det förmodligen inte kommer att låta konstant från konstverket, då det helt är beroende av hur ofta någon står vid ett annat konstverk och skickar ett meddelande. Resultatet av testet blev att ljudet hördes väldigt svagt i den miljön. Projektgruppen valde därmed att göra ett andra test i en mer lämplig miljö och ställde sig innanför bullerstaketet längs med Nyhemsområdet och Laholmsvägen. Samma procedur genomfördes och testet resulterade i ett bättre resultat. Värt att tillägga är att ljud från fordon fortfarande hördes men då mer i bakgrunden, så som det troligen kommer att vara i en mer central miljö. Se Bild 6 och 7.



Bild 6 och 7 är tagna under utomhustestet. Fotograf: Emma Bäckman

\section{Fastsättning av teknik}

Projektgruppen har brainstormat kring hur tekniken ska sättas fast inuti konstverket.

Brainstorming har skett inom gruppen men även i samråd med Daniel Petersson. Det förslag som blev det slutgiltiga är att använda sig av någon typ av stål som "hyllplan". Daniel förklarade att mikrofonen brusade men när de använde sig av metall vid toppen av kretskortet så upphörde bruset. Detta beror troligen på att GPRS-sändaren skickar ut signaler som stör mikrofonen. Förslaget är därför en U-formad stålbit med ett hål på varje sida. I det översta hålet är tanken att kretskortet ska gängas fast och i de andra två hålen ska högtalarna föras in och eventuellt limmas fast. För att batteriet ska sitta på plats kommer ett "hyllplan" nedanför kretskortet att behövas. För att få både den U-formade plåtbiten samt hyllplanet för batteriet att sitta fast föreslås det att man på något sätt skruvar fast dessa med hjälp av de fyra varmformade konstruktionsrören. En skiss på förslaget presenteras i Figur 2. 




Figur 2, skissad av Anna Westberg

\section{Handlingsplaner}

Efter examensarbetets avslut kommer alternativ för att ta fram stolpar med andra anslutningar för bland annat el och internet finnas möjliga för utveckling. Det finns inte tillräckligt med pengar till detta i prototypstadiet och därmed kommer det först vara möjligt att genomföra andra versioner av konstverket efter examensarbetets avslut då teststolparna har utvärderats.

För att underlätta för den/de personer som vill använda dessa förslag istället för de lösningar som prototypen utgår ifrån har projektgruppen skrivit ihop handlingsplaner med den information som har samlats in under examensarbetets gång angående detta.

Varje handlingsplan presenterar ett handlingsförslag med en inledande beskrivning följt av ett tillvägagångssätt, en kortare sammanfattning samt vad som är viktigt att tänka på vid genomförandet av handlingsplanen. Handlingsplanerna presenteras i Bilaga 13. 


\section{Resultat}

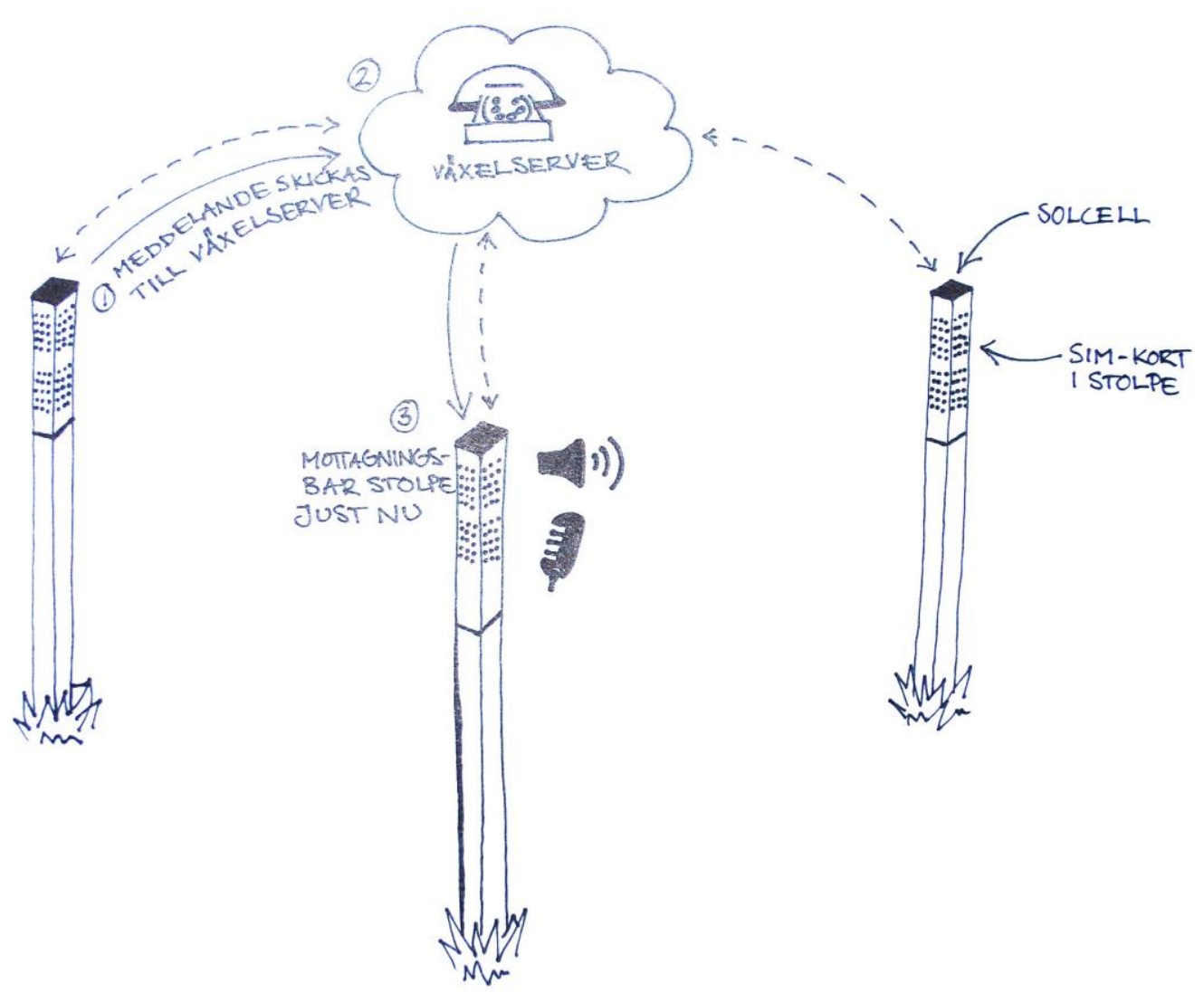

Figur 3, Översikt av systemet. Skissad av Anna Westberg

Collective Communication fungerar med hjälp av en mobiltelefonkrets där systemet slumpmässigt ringer till olika stolpar. Detta innebär att ett meddelande kommer att spelas in lokalt på ett minne när en person pratar in i konstverket. Samtidigt som personen pratar in ett meddelande ringer konstverket upp ett annat konstverk inom nätverket slumpmässigt som då ska ta emot meddelandet. På grund av detta, undviks fördröjning när konstverket ringer upp det mottagande konstverket även fast de inte har direktkontakt från början. Meddelandet hörs först när mottagande konstverk "lyfter på luren" och därmed undviks att ringsignalen spelas upp. ${ }^{36}$

\subsection{Prata in ett meddelande}

För att konstverket ska dra så lite ström som möjligt befinner den sig när den inte används i ett "sov-läge". Systemet är därmed så gott som "avstängt" och det enda som är aktivt under denna tid är en mikroprocessor. När en person sedan pratar in i konstverket detekterar processorn detta och väcker upp hela systemet som genast börjar spela in meddelandet. För att spela in meddelandet används en mikrofon som genererar en svag analog signal, som i sin tur förstärks med en förstärkarkrets. ${ }^{37}$

\footnotetext{
${ }^{36}$ Daniel Pettersson, Assisting Systems

${ }^{37}$ Ibid
} 


\subsection{Ringa upp konstverket}

När en person pratar in i ett av dessa konstverk aktiveras en GSM-modul via mikroprocessorn. När GSM-modulen har fått kontakt med det mobila nätverket ringer mikroprocessorn upp ett ledigt konstverk. Valet av konstverk sker slumpmässigt och väljs från en telefonlista. När det mottagande konstverket "lyfter på luren" kommer meddelandet att spelas upp som tidigare lagrats på ett minne. För att detta ska vara möjligt används en digital till analog konverterare. ${ }^{38}$

\subsection{Uppspelning av meddelande}

När det slumpmässigt valda konstverket "lyfter på luren" aktiveras högtalaren och meddelandet spelas upp. För att förstärka ljudet används en förstärkarkrets och när meddelandet har spelats upp "lägger konstverket på luren" och går i sovläge igen. ${ }^{39}$

\subsection{Sammanfattning av Collective Communication}

- Höjden på konstverket kommer att vara 1,50 meter över marken

- Materialet på konstverket är varmformat konstruktionsrör som kommer att skyddas med tjockfilmspassificering och därefter våtlackeras

- Symbolerna till konstverket kommer att "klistras fast" likt reklam på till exempel bilar

- Låsningen upptill av servicedelen kommer att göras med fyra säkerhetsskruvar

- Fastsättningen i marken kommer genomföras genom att gräva ett hål i marken, föra ner betongplinten som är fastsatt i konstverket, täcka över betongplinten med sand och sedan lägga eventuella plattor eller stenar ovanpå

- En solcell kommer att placeras på konstverkets topp i en försänkning

- Tyget som valts för att skydda tekniken är silikonbehandlad markisväv och kommer att täcka hela insidan av konstverket

- Fastsättning av tekniken är ännu inte fastställt men projektgruppen har redovisat ett förslag under Kapitel 4

\footnotetext{
${ }^{38}$ Daniel Pettersson, Assisting Systems

${ }^{39}$ Ibid
} 


\section{Diskussion och reflektion}

\subsection{Affärsplan}

Då Collective Communication är ett konstverk faller det inte under samma lagar och regler som gäller för produkter som ska säljas till privatpersoner. Detta innebär att det inte går att upprätta en affärsplan för konstverket då det inte är tänkt att säljas till privatpersoner.

Collective Communication ska säljas till kommuner som vill köpa in konstverket för att installera det på offentliga platser inom sin kommun. Om produkten marknadsförs på rätt sätt kommer kommunerna att vilja köpa konstverket inom rimligt pris. Denna uppgift ligger som avgränsning i examensarbetet då studenterna i samråd med uppdragsgivaren har lämnat det helt till honom.

\subsection{Framtid}

Collective Communications framtid ser lovande ut. Examensarbetets uppdragsgivare har i dagsläget flera intresserade kommuner inom Sverige som är villiga att köpa in produkten. Målet när examensarbetet är avslutat är att installera den första testserien av produkten i intresserade kommuner inom Halland. På så sätt blir Hallands kommuner testutvärderare av produkten för att undersöka intresset bland allmänheten för denna produkt och se hur den fungerar i verkligheten med alla påfrestningar på teknik och liknande.

Därefter finns möjlighet att utveckla flera versioner av produkten enligt de handlingsplaner studenterna har tagit fram. Fler testserier kommer att krävas för detta.

När examensarbetet avslutas i maj 2016 kommer examensarbetet helt att lämnas över till uppdragsgivare Robert Hais för möjlighet till vidareutveckling. Fortsatta samarbetsmöjligheter med examensarbetets teknikansvariga, företaget Assisting systems, kommer att finnas och även vidareutveckling genom de föreslagna handlingsplanerna.

Genom examensarbetets gång har studenterna hittat alternativa lösningar som inte funnits möjlighet att undersöka närmare och gå vidare med under denna tid. Det handlar om att göra Collective Communication till hotspots där trådlöst nätverk skulle kunna sändas ut till stadens invånare. Det finns städer som har som mål att installera hotspots i centrum och om det är möjligt att integrera det i Collective Communication kommer internet för konstverket finnas tillgängligt på ett enkelt sätt samtidigt som städerna får trådlöst nätverk tillgängligt. Det blir dessutom en extra vinkel ur marknadsföringssynpunkt för Collective Communication.

Ett annat framtida förslag är att anpassa Collective Communication till företag. Som till exempel en intern kommunikationsportal mellan ett företags olika kontor, där anställda kan skicka korta meddelanden till varandra. Collective Communication kan då vara en byggsten i arbetet för att öka trivseln på ett företag.

\subsection{Hållbarhet, Genus och Etik}

Collective Communication är ett konstverk för offentliga platser vilket gör att den påverkar olika aspekter inom både hållbarhet, miljö och genus. I och med att det är en produkt anpassad för att säljas till kommuner och inte till privatpersoner ger den dock en mindre påverkan inom hållbarhet och miljö då den inte tillverkas i stora volymer. 
Tanken är att produkten ska hålla i många år och tåla både väder och vind samt lättare slitage. På så sätt sparas miljön genom att inte behöva tillverka nya stolpar på löpande band och produkten blir därmed hållbar i ett längre perspektiv.

Collective Communication är en produkt som kommer att tillverkas efter beställning för att det på så sätt inte ska behövas lager. Detta betyder att det inte kommer att finnas fler antal produkter än det finns efterfrågan. Materialet i produkten har självklart en inverkan på miljön. I och med att det är mer av en önskvärd produkt än en nödvändig sådan påverkar den miljön negativt på ett sätt som kanske inte hade varit lika påtagligt om produkten hade varit nödvändig. Trots det är den inte en stor miljöbov mer än i själva tillverkningen.

Då produkten är ett konstverk för offentliga platser är genusaspekten en viktig del av produkten. Speciellt då huvudsyftet med Collective Communication är att belysa alla människors lika värde oavsett kön, ålder, utseende, sexuell läggning med mera. Offentliga konstverk påverkar oss mer än vi tror vilket diskuteras i stycket Teori- och referensram. Därför har konstverket möjlighet att påverka människans lika värde på det sättet som examensarbetets uppdragsgivare vill.

Socialt inverkar Collective Communication till en ökad medvetenhet om vikten av att prata med varandra i verkligheten. Vi lever i en värld där våra telefoner, datorer och dess innehåll betyder mer för oss än att interagera socialt med människor i verkligheten.

\subsection{Slutsats}

Studenterna som har jobbat med detta projekt är nöjda med dess utveckling och resultat. Det har varit ett lärorikt projekt som har gett studenterna erfarenhet av att vara projektledare i ett projekt som resultatmässigt kommer att bli verklighet. Det finns dock delar som hade kunnat göras på ett annorlunda sätt och delar som skulle ha gjorts tidigare under examensarbetets gång.

Genom en lärorik utbildning har studenterna haft stor nytta av den kunskap de samlat på sig under programmets gång. Denna kunskap ligger till grund för hur examensarbetet har genomförts och har gjort rapportskrivandet enklare då erfarenheter sedan tidigare projekt har förts in i examensarbetet.

Rapporten började skrivas i god tid och har därför också blivit klar i tid för inlämning. Arbetet med prototypen har däremot dragit ut på tiden på grund av att ett antal olika parter ska göra sina delar i examensarbetet innan nästa steg i processen kan tas vid. På så vis är de olika samarbetsparterna beroende av varandra för att prototypen ska kunna tillverkas enligt tidsplan. Detta har inte gått helt enligt plan och prototyperna som skulle vara helt klara till redovisningen av examensarbeten den 18 maj 2016 istället har som mål att vara klara till UtExpo som startar en vecka senare.

Med de erfarenheter vi har tagit med oss från detta examensarbete vill vi uppmuntra andra till att genomföra ett examensarbete som intresserar er. Det blir otroligt mycket lättare att genomföra ett projekt som är både roligt och givande. Våga välja ett projekt som är annorlunda eller som egentligen ligger utanför ert kunskapsområde. Vi hade inga tidigare erfarenheter av att samarbeta med en konstnär eller att leda ett projekt av denna storlek innan vi tog oss an detta projekt, men vi är otroligt glada och stolta över det resultat vi har när examensarbetet nu avslutas. 
Vi vill slutligen belysa vikten av att lägga tid på att genomföra en realistisk och bra tidsplan för att underlätta arbetet under examensarbetets gång. 


\section{Referenser}

\subsection{Litteratur}

Tonnquist, Bo; Projektledning; 5:e upplagan; Stockholm, Bo Tonnquist och Sanoma

Utbildning AB; 2014

Ottosson Stig; Dynamisk innovationsverksamhet; Tervix förlag; 2012

Österlin Kenneth; Design i fokus för produktutveckling; 3:e utökade upplagan; Liber AB; 2011

Holmdahl, Lars; Lean Product Develompment På Svenska; version 1.6. Göteborg, DigitaltryckNu; 2010

\subsection{Artiklar}

Sussman Jeffrey; Art in public spaces; publicerad 23 juli 2013

Persson Hans, Åhman Henrik, Arvei Ynglin Alexander, Gulliksen Jan; Universal design, inclusive design, accessible design, design for all: different concepts - one goal? On the concept of accessibility - historical, methodological and philosophical aspects; publicerad 14 maj 2014

\subsection{Internet}

http://www.foreningsresursen.fi/foreningsarbete/metoder/brainstorming/ (hämtad 2016-03-29) http://www.effectsoft.se/om-oss-25731985 (hämtad 2016-03-15)

https://sv.wikipedia.org/wiki/Datormoln (hämtad 2016-03-15)

http://www.mindmapping.com/sv/teorin-bakom-mind-maps.php (hämtad 2016-02-29)

http://www.gore-tex.com/en-us/technology/what-is-gore-tex (hämtad 2016-04-12)

http://www.fonsterinredarna.se (hämtad 2016-04-12)

http://sbi.se/uploads/source/files/Artiklar/Konstruktionsstal.pdf (hämtad 2016-03-27)

http://sbi.se/uploads/source/files/Artiklar/Rosttroga_stal_rev20150226.pdf (hämtad 2016-03-

27)

http://sbi.se/uploads/source/files/Artiklar/Stalets_egenskaper.pdf (hämtad 2016-03-27)

http://www.begroup.com/sv/BE-Group-sverige/Produkter/Rostfritt/Produktinformation/Omrostfritt-stal/ (hämtad 2016-03-27)

https://www.kjell.com/se/fraga-kjell/hur-funkar-det/natverk/hemnatverk/battre-tradlostackning (hämtad 2016-05-03)

http://www.studera.com/tranano/fysik/Elektricitet/Transf.html (hämtad 2016-05-05)

http://www.dinbyggare.se/sa-har-fungerar-husets-elsystem/ (hämtad 2016-05-05)

https://www.wurth.se/produkter/fastmaterial/sakerhetsskruvar--

tillbehor/platskruvar/sakerhetsskruv-forsankt-huvud/sakerhetsskruv-ftxp/ (hämtad 2016-05-

06)

https://www.wurth.se/produkter/fastmaterial/sakerhetsskruvar--

tillbehor/platskruvar/sakerhetsskruv-forsankt-huvud/sakerhetsskruv-ftxp/ (hämtad 2016-05-

06)

http://www.sweclockers.com/forum/trad/1334344-rasberry-pi-eller-arduino-vad-ar-skillnaden (hämtad 2016-02-29)

https://www.tiny-circuits.com/products/tiny-duino.html (hämtad 2016-02-29)

http://www.kjell.com/se/fraga-kjell/teman/raspberry-pi (hämtad 2016-02-29) 
http://www.conrad.se/?websale8=conrad-

swe\&pi=1406729\&ws_tp $1=$ cp\&ref=PLA_KOMPONENTER\&subref=1406729\&utm_source $=$ PLA_KOMPONENTER\&utm_medium=PLAfeed\&utm_campaign=PLA_KOMPONENTE R_feed\&utm_content $=1406729 \&$ gclid $=$ Cj0KEQiArou2BRDcoN_c6NDI3oMBEiQANeix5gg keNFGGp_TZ4mYg25-sCCd-aVudi3hkIknopWQfPkaAp5r8P8HAQ (hämtad 2016-02-29) http://www.electrokit.com/ (hämtad 2016-02-29)

http://www.electrokit.com/miniatyrhogtalare-o25mm-8ohm-3w.52371 (hämtad 2016-02-29)

http://www.electrokit.com/hogtalare-8ohm-o21mm-0-1w.41741 (hämtad 2016-02-29)

http://www.electrokit.com/hogtalare-8ohm-o30mm-0-2w-pcb.49568 (hämtad 2016-02-29)

http://www.electrokit.com/hogtalare-8ohm-o40mm-0-25w-tunn.48834 (hämtad 2016-02-29)

http://www.electrokit.com/hogtalare-8ohm-o40mm-0-25w-tunn.48834 (hämtad 2016-02-29)

http://www.electrokit.com/electret-mikrofon-o9-7-x-6-7mm.43370 (hämtad 2016-02-29)

\subsection{Personer}

Staffan Karlsson, Ljudtekniker

Erik Halvordsson, HMS

Hans Ripén, Elingenjör, Halmstad Kommun

Daniel Pettersson, Assisting Systems 
8. Bilagor

Bilaga 1 - Projektplan, 4 sidor

Bilaga 2 - PEST-analys, 1 sida

Bilaga 3 - SWOT-analys, 1 sida

Bilaga 4 - Porters branschstrukturanalys, 1 sida

Bilaga 5 - Canvasmodellen, 1 sida

Bilaga 6 - Mindmaps, 6 sidor

Bilaga 7 - Tidsplanering hösten 2015, 1 sida

Bilaga 8 - Tidsplanering våren 2016, 4 sidor

Bilaga 9 - Moodboard, 1 sida

Bilaga 10 - Themeboard, 1 sida

Bilaga 11 - Personas, 2 sidor

Bilaga 12 - Mötesanteckningar, 2 sidor

Bilaga 13 - Handlingsplaner, 5 sidor

Bilaga 14 - Ritningar/bilder, 2 sidor 


\section{Bilaga 1 - Projektplan}

\section{Projektorganisation}

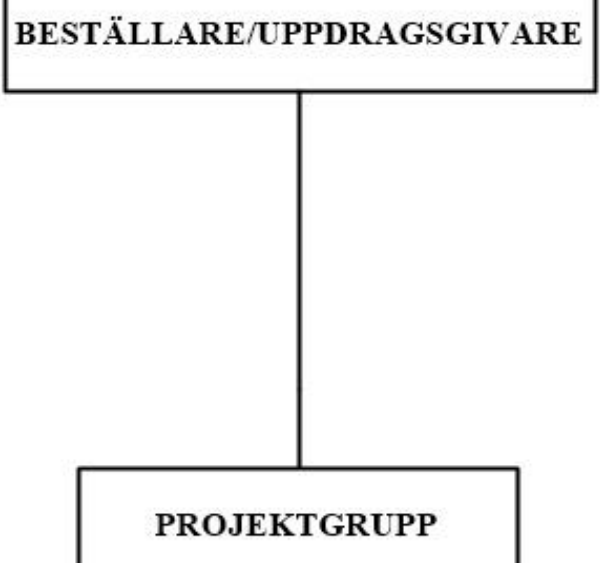

Projektorganisationen består av studenterna som jobbar med examensarbetet, Anna Westberg och Emma Bäckman. Projektorganisationen styrs av uppdragsgivaren Robert Hais och även studenternas handledare från Högskolan i Halmstad finns till hands, Hans-Erik Eldemark.

\section{Krav och önskemål}

Krav och önskemål genererar i att projektgruppen har riktlinjer att följa och får en struktur på arbetet. Uppdragsgivaren har ställt nedanstående krav på prototypen.

- Olika miljöaspekter ska tas hänsyn till, detta kan vara bland annat materialval och fastsättning i marken

- Tekniken inuti samt konstverket i sig måste tåla väder och vind

- Hållfastheten är viktigt vid eventuell vandalisering

- Se över tillgängligheten, bland annat höjdanpassning

- Eltillförsel samt internetuppkoppling behövs

- Någon typ av programmering för att kunna skicka samt ta emot ljudfiler

Projektgruppen har satt upp egna krav som ska ha uppfyllts vid examensarbetets slut:

- Projektgruppen ska känna sig stolta över det som har åstadkommits

- Projektgruppen ska känna att examensarbetet genererat i nya kunskaper 


\section{Avgränsningar}

För att projektgruppen ska ha möjlighet att fullfölja examensarbetet under avsatt tidsperiod samt ha möjlighet att göra ett fullständigt arbete kommer examensarbetet att avgränsas. Nedanstående punkter kommer projektgruppen inte att fokusera på.

- Projektgruppen kommer inte att fokusera på en framtida webbsida

- Projektgruppen kommer inte att sköta kontakten med de olika kommunerna gällande försäljning av Collective Communication

- Projektgruppen kommer inte att ha tillräckligt med kunskap för att kunna utforma programmeringen på egen hand utan kommer att behöva anlita hjälp

\section{Intressentanalys och intressenthantering}

Intressenter innebär de personer som kan komma i kontakt med examensarbetet på något sätt. Exempelvis via sponsorer eller olika samarbeten. Det finns tre olika typer av intressenter beroende på vilken roll de har för examensarbetet, dessa är kärnintressenter, primärintressenter och sekundärintressenter

\section{Kärnintressenter}

Beställare/uppdragsgivare: A-priori, Robert Hais

Projektgruppens medlemmar: Anna Westberg och Emma Bäckman

Samarbetspartners: Assisting Systems

Handledare: Hans-Erik Eldemark, Högskolan i Halmstad

\section{Primärintressenter}

A-Prioris kunder: Kommuner

Framtida användare av kommunikationsportalen

\section{Sekundärintressenter}

Halmstad Stadsnät

Sponsorer

Företag som säljer komponenter till prototypen

\section{Budget}

Examensarbetet finansierades med 30.000 kronor som mottogs av uppdragsgivaren från ALMI. Projektgruppen räknar med att vid anställning av programmerare kommer kostnader till detta att uppgå till cirka 25.000 kronor och därmed går övriga 5.000 kronor till tester samt framställning av prototyp.

\section{Tidsplanering}

En tids- och resursplanering görs för examensarbetet i två etapper. Den första görs till konceptvalsredovisningen i december 2015 och därefter görs tre stycken för vårterminen fram till redovisningen i maj, samt en tidsplanering för skolan. Nedan syns tidsplaneringen för hösten 2015 samt en utav de fyra för våren. En tydligare bild av alla tidsplaneringar finns i Bilaga 7 samt 8 







\section{Riskanalys och riskhantering}

Projektgruppen valde att göra en riskanalys på examensarbetet för att i ett tidigt stadie kunna identifiera eventuella risker och på så sätt kunna minimera risken för att de uppstår. I riskanalysen kommer det att tittas på varje enskild risk, sannolikheten att den uppstår samt konsekvensen av att den uppstår. För att detta ska kunna förhindras får varje risk ett riskvärde och även en åtgärd kommer att föreslås.

\begin{tabular}{|c|c|c|c|c|}
\hline TYP AV RISK & SANNOLIKHET (1-5) & KONSEKVENS (1-5) & RISKVÄRDE & ÅTGÄRD \\
\hline $\begin{array}{l}\text { 1. Tekniska problem med } \\
\text { till exempel dator }\end{array}$ & 2 & 5 & 10 & $\begin{array}{l}\text { Spara allt arbete på flera } \\
\text { platser. Användning av } \\
\text { Google Drive }\end{array}$ \\
\hline 2. Sjuk projektmedlem & 2 & 2 & 4 & $\begin{array}{l}\text { Meddela i tid. Arbeta med } \\
\text { uppgifter hemma }\end{array}$ \\
\hline 3. Inställt handledarmöte & 2 & 3 & 6 & Boka nytt möte \\
\hline $\begin{array}{l}\text { 4. Inställt möte med } \\
\text { uppdragsgivare }\end{array}$ & 1 & 4 & 4 & Boka nytt möte \\
\hline $\begin{array}{l}\text { 5. Missnöjd } \\
\text { uppdragsgivare }\end{array}$ & 1 & 5 & 5 & $\begin{array}{l}\text { Kommunikation och } \\
\text { uppdatering av arbetets } \\
\text { gång är A \& O. Skrivit } \\
\text { avtal }\end{array}$ \\
\hline 6. Tidsplan följs ej & 1 & 5 & 5 & $\begin{array}{l}\text { Ska checkas av } \\
\text { kontinuerligt. Viktigt med } \\
\text { delmål }\end{array}$ \\
\hline $\begin{array}{l}\text { 7. Osämja i } \\
\text { projektgrupppen }\end{array}$ & 1 & 5 & 5 & $\begin{array}{l}\text { Kommunicera med } \\
\text { varandra. Rättvis } \\
\text { fördelning av uppgifter }\end{array}$ \\
\hline $\begin{array}{l}\text { 8. Osämja mellan } \\
\text { projektgrupp och } \\
\text { uppdragsgivare }\end{array}$ & 1 & 5 & 5 & $\begin{array}{l}\text { Kommunikation och } \\
\text { uppdatering av arbetets } \\
\text { gång är A \& O. Skrivit } \\
\text { avtal } \\
\end{array}$ \\
\hline
\end{tabular}


Bilaga 2 - PEST-analys

\begin{tabular}{|c|c|}
\hline Politisk & Ekonomisk \\
\hline Allas lika värde, "design för alla" & Ingen kostnad för användarna, dyr produkt/styck \\
\hline Social & Teknisk \\
\hline $\begin{array}{c}\text { Uppmärksammat i media att användningen av IT- } \\
\text { kommunikation ökar konstant, populärt med konstverk på } \\
\text { offentliga platser }\end{array}$ & All produktion på samma ställe, \\
\hline
\end{tabular}




\section{Bilaga 3 - SWOT-analys}

SWOT-analys på produkten

\begin{tabular}{|c|c|}
\hline STYRKOR & SVAGHETER \\
\hline $\begin{array}{c}\text { Två projektmedlemmar som samarbetar, samarbete med ett } \\
\text { mindre företag (beställare), samarbete med datoringenjörer, } \\
\text { lång tid att genomföra projektet på }\end{array}$ & $\begin{array}{c}\text { Svårförklarat, krävs samarbeten för att få tekniken att fungera, } \\
\text { stort projekt, svårt att enkelt hitta information och hjälp då } \\
\text { produkten är väldigt nischad }\end{array}$ \\
\hline MÖJLIGHETER & HOT \\
\hline $\begin{array}{c}\text { Möjlighet till fortsatt arbete efter examensarbetets slut, } \\
\text { samarbetsmöjligheter med andra program och företag, möjlighet } \\
\text { till att knyta nya kontakter och få nya efarenheter }\end{array}$ & $\begin{array}{c}\text { Datorer eller annan teknik som krånglar, problem med lösningar, } \\
\text { samarbeten fungerar inte, meningsskiljaktigheter inom } \\
\text { projektgruppen eller med beställaren }\end{array}$ \\
\hline
\end{tabular}

SWOT-analys på examensarbetet

\begin{tabular}{|c|c|}
\hline STYRKOR & SVAGHETER \\
\hline $\begin{array}{c}\text { Två projektmedlemmar som samarbetar, samarbete med ett } \\
\text { mindre företag (beställare), samarbete med datoringenjörer, } \\
\text { lång tid att genomföra projektet på }\end{array}$ & $\begin{array}{c}\text { Svårförklarat, krävs samarbeten för att få tekniken att fungera, } \\
\text { stort projekt, svårt att enkelt hitta information och hjälp då } \\
\text { produkten är väldigt nischad }\end{array}$ \\
\hline MÖJLIGHETER & HOT \\
\hline $\begin{array}{c}\text { Möjlighet till fortsatt arbete efter examensarbetets slut, } \\
\text { samarbetsmöjligheter med andra program och företag, möjlighet } \\
\text { till att knyta nya kontakter och få nya efarenheter }\end{array}$ & $\begin{array}{c}\text { Datorer eller annan teknik som krånglar, problem med lösningar, } \\
\text { samarbeten fungerar inte, meningsskiljaktigheter inom } \\
\text { projektgruppen eller med beställaren }\end{array}$ \\
\hline
\end{tabular}




\section{Bilaga 4 - Porters branschstrukturanalys}

Kunder: Kunderna för denna produkt är kommunerna då det är dem som är potentiella köpare.

Substitut: I och med att det inte finns någon liknande produkt finns det heller inget direkt substitut. Dock är internet en viss form av substitut då det går att skicka motsvarande meddelanden där.

Nya aktörer: Eftersom detta är en ny och hittills okänd produkt, dessutom en produkt för det offentliga rummet, är nya aktörer inget direkt hot då det i dagsläget inte finns någon konkurrens.

Leverantörer: De komponenter som kommer att användas till produkten är komponenter som enkelt går att få tag på hos ett flertal olika leverantörer.

Existerande företag: I dagsläget finns inga existerande företag som tillverkar denna typ av produkt då den är helt ny på marknaden. I och med att det inte är en konkurrenskraftig produkt som ska säljas i en vanlig dagvaruhandel eller liknande finns troligen inte heller ett lika stort behov för andra företag att konkurrera ut denna produkt. 
Bilaga 5-Canvasmodellen

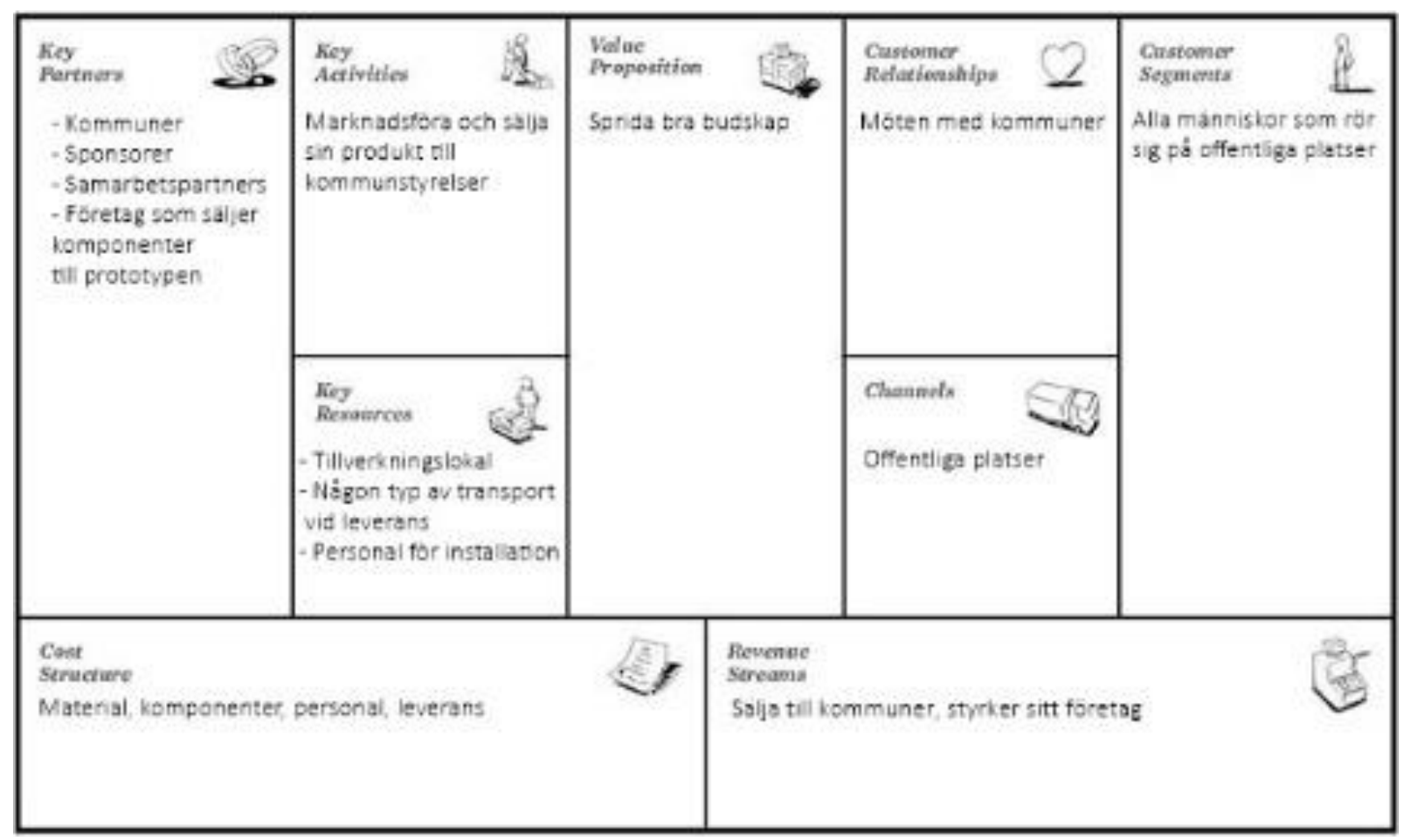


Bilaga 6-Mindmaps

Design på Collective Communication:

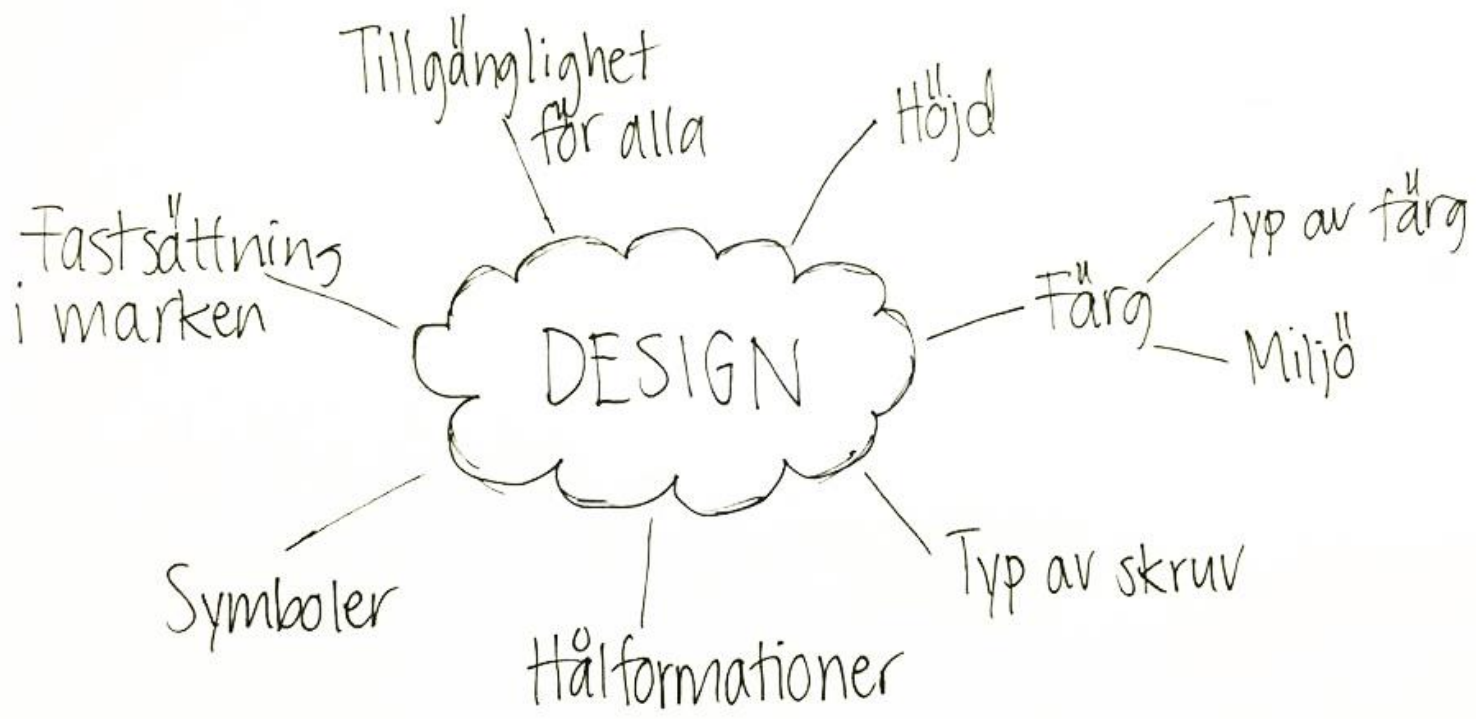

Låsning upptill:

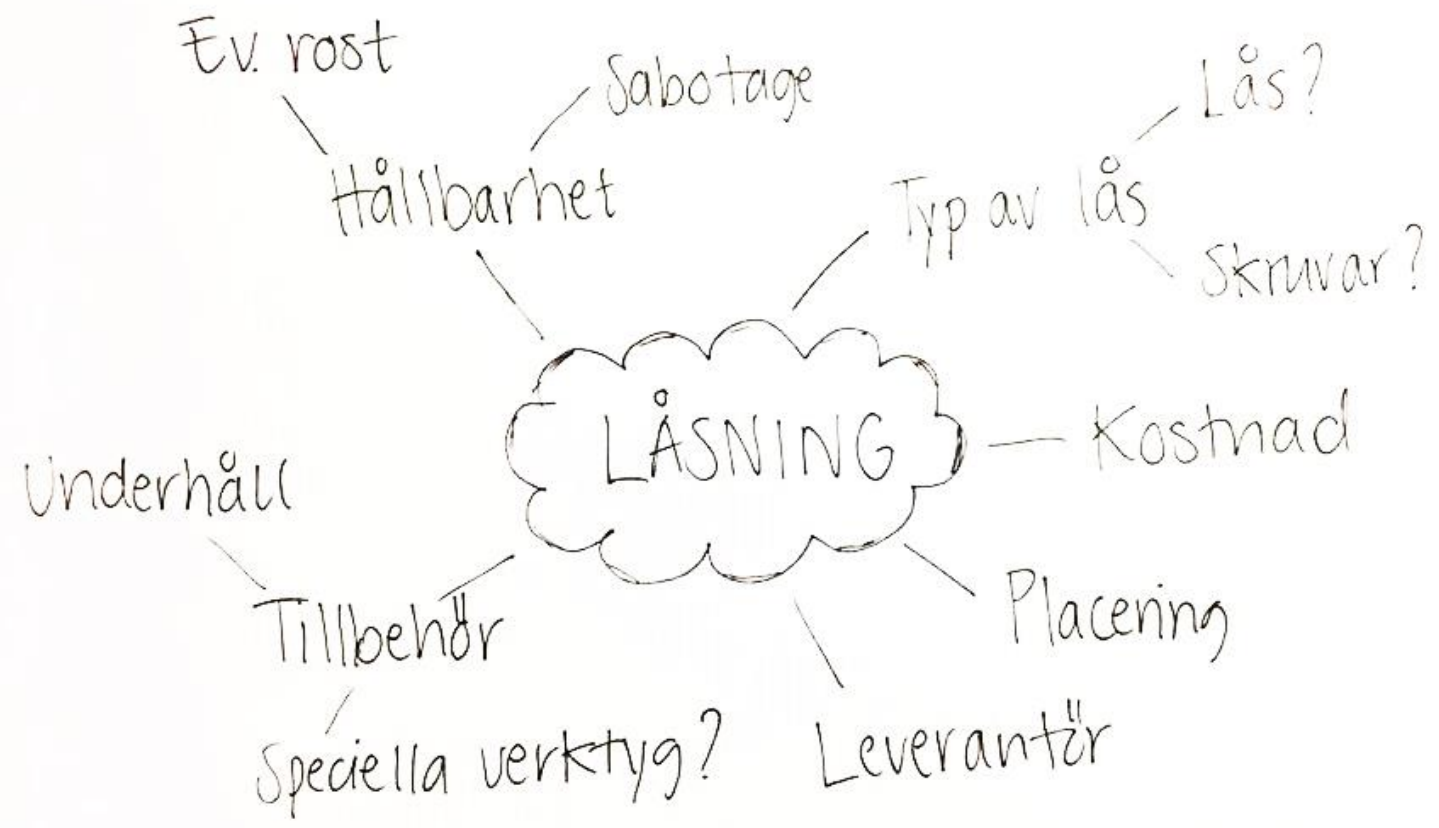


Fastsättning i marken:

Betongplint Littcykelställ

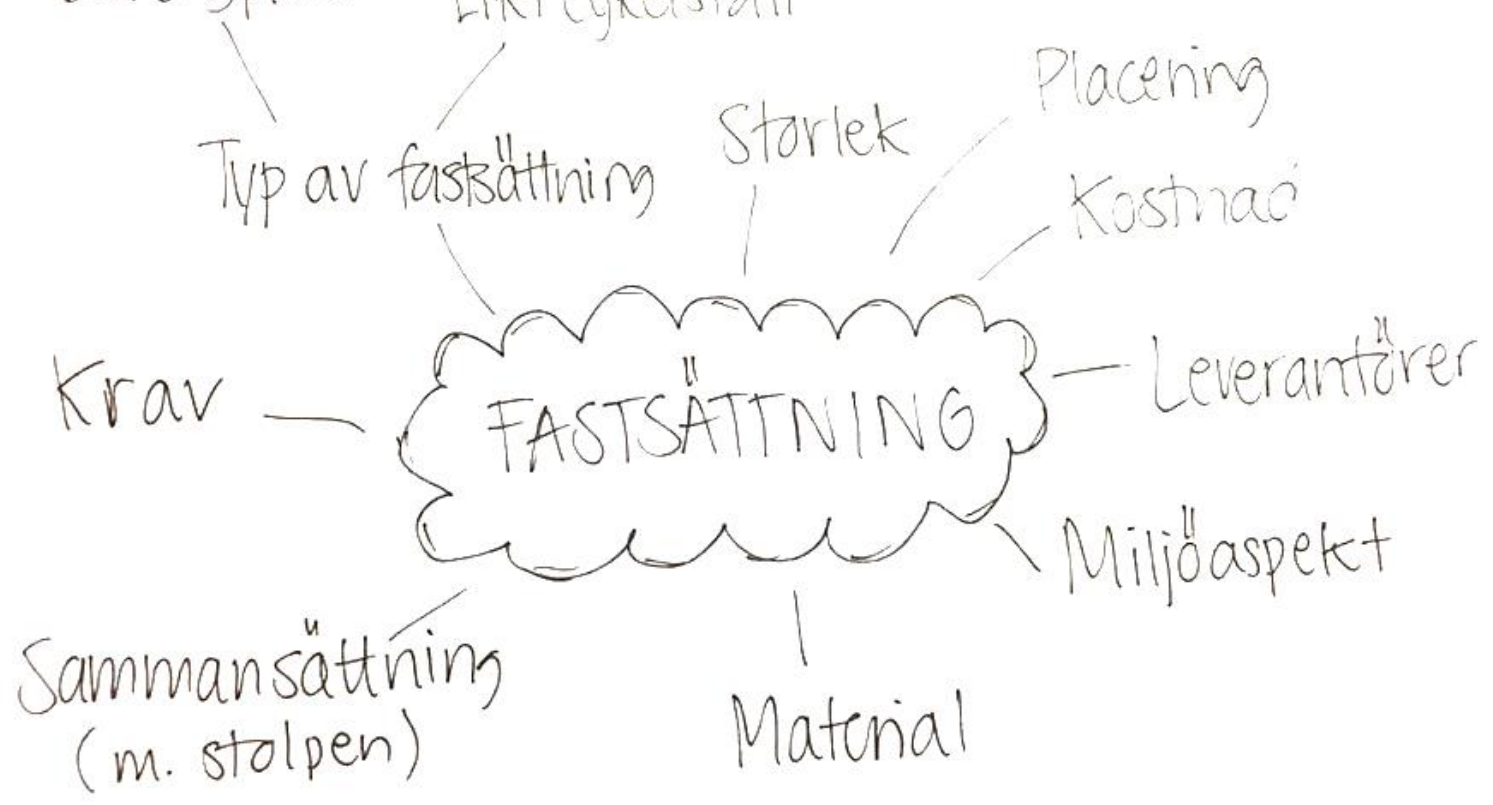

Materialval till Collective Communication:

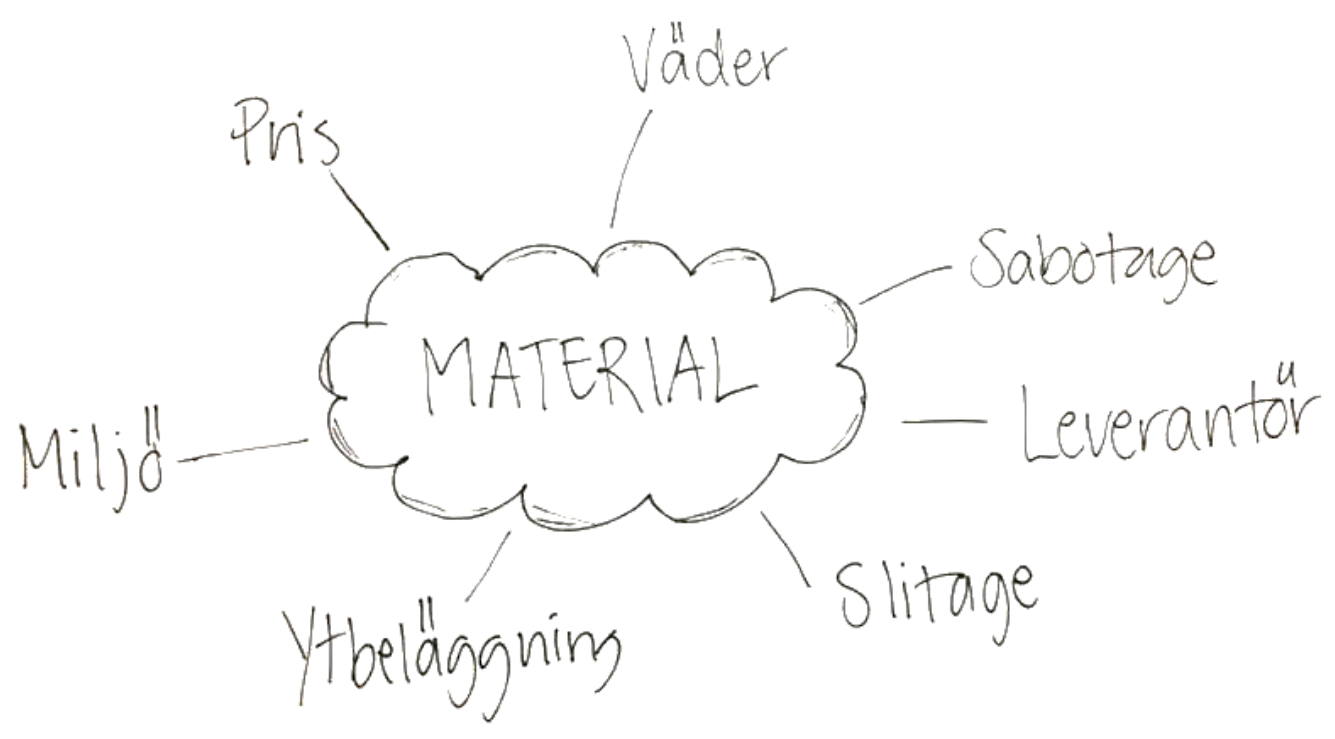

Bilaga 6

2(6) 
Mikrofon:

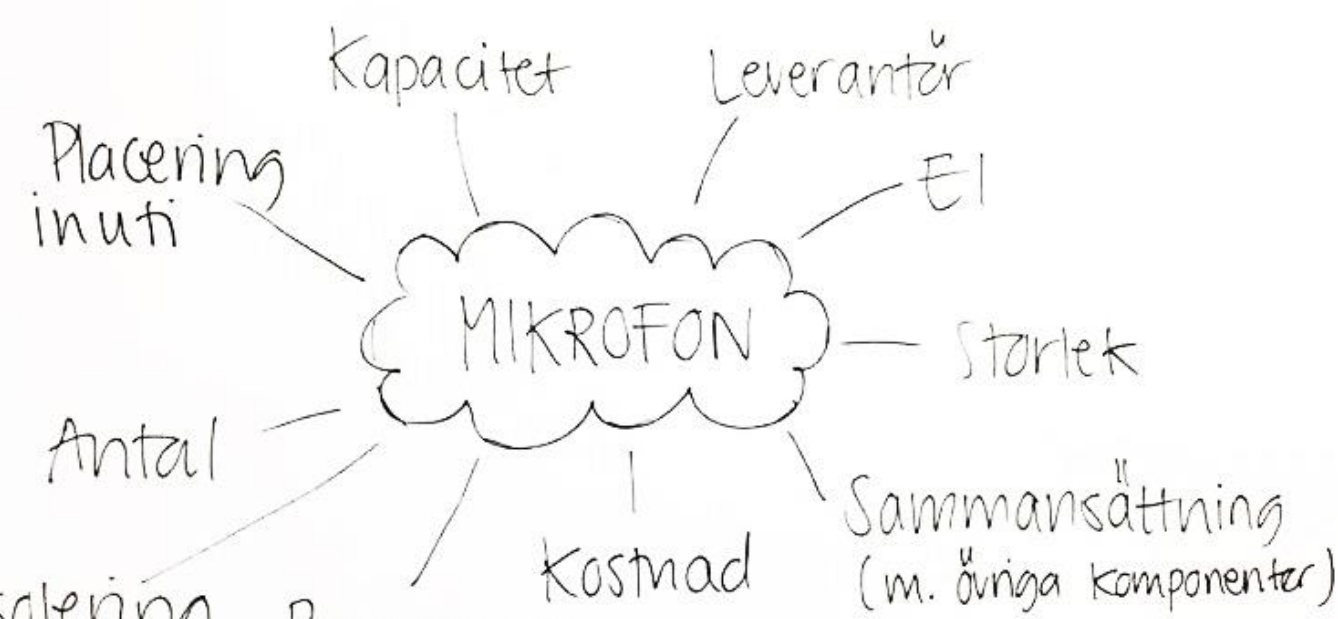

Isolening Progranmering

Högtalare:

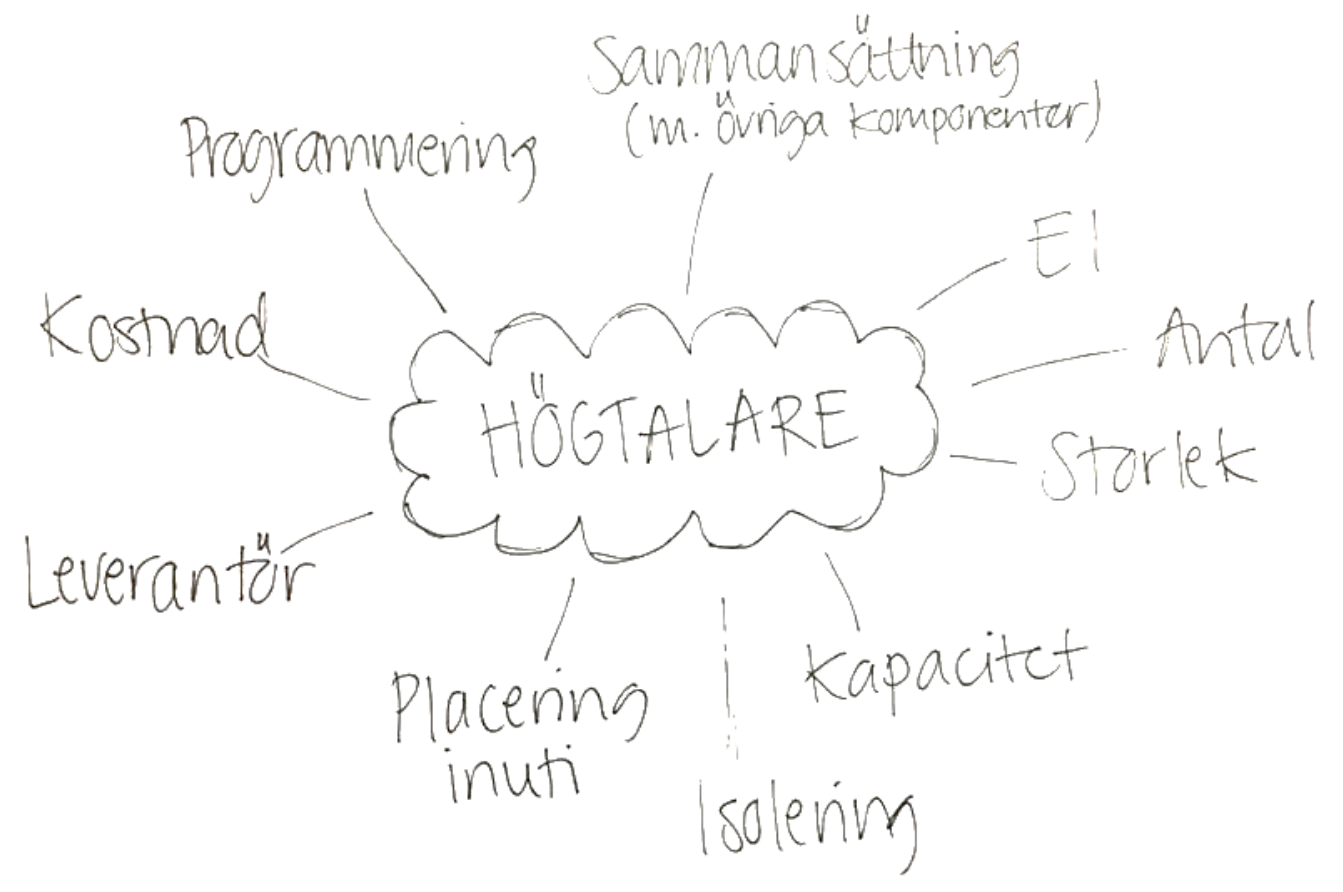

Bilaga 6

3(6) 
Enkortsdator:

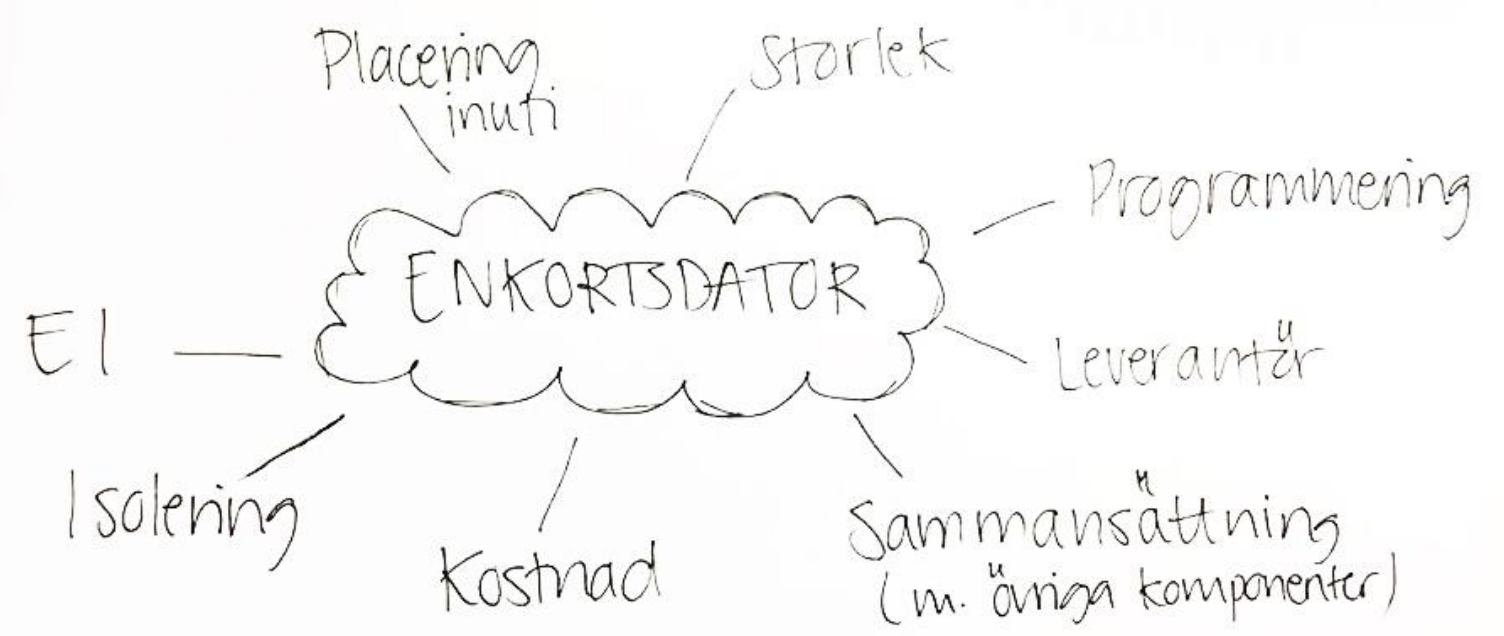

Hålformationer:

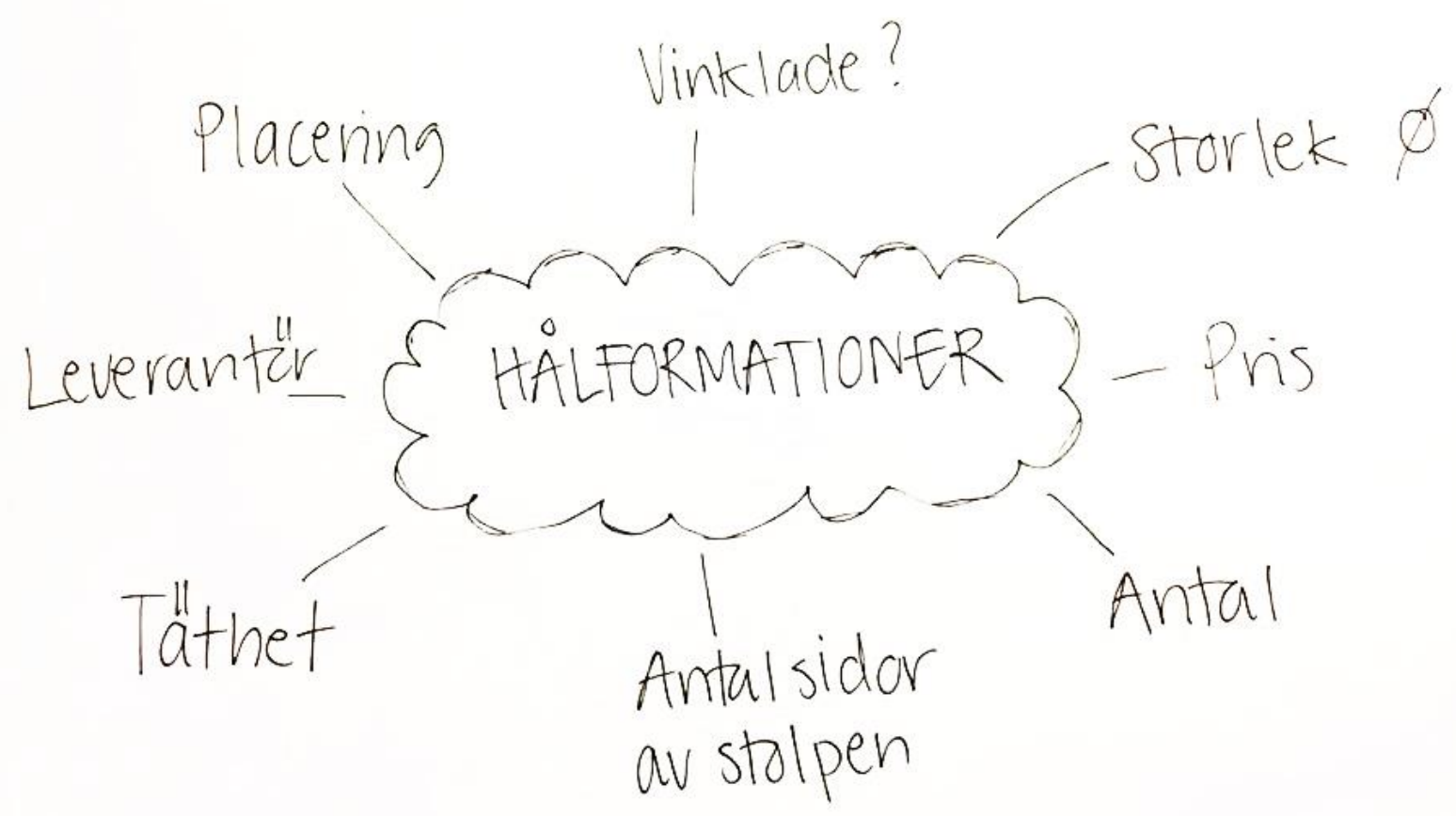

Bilaga 6

$4(6)$ 
Sensor:

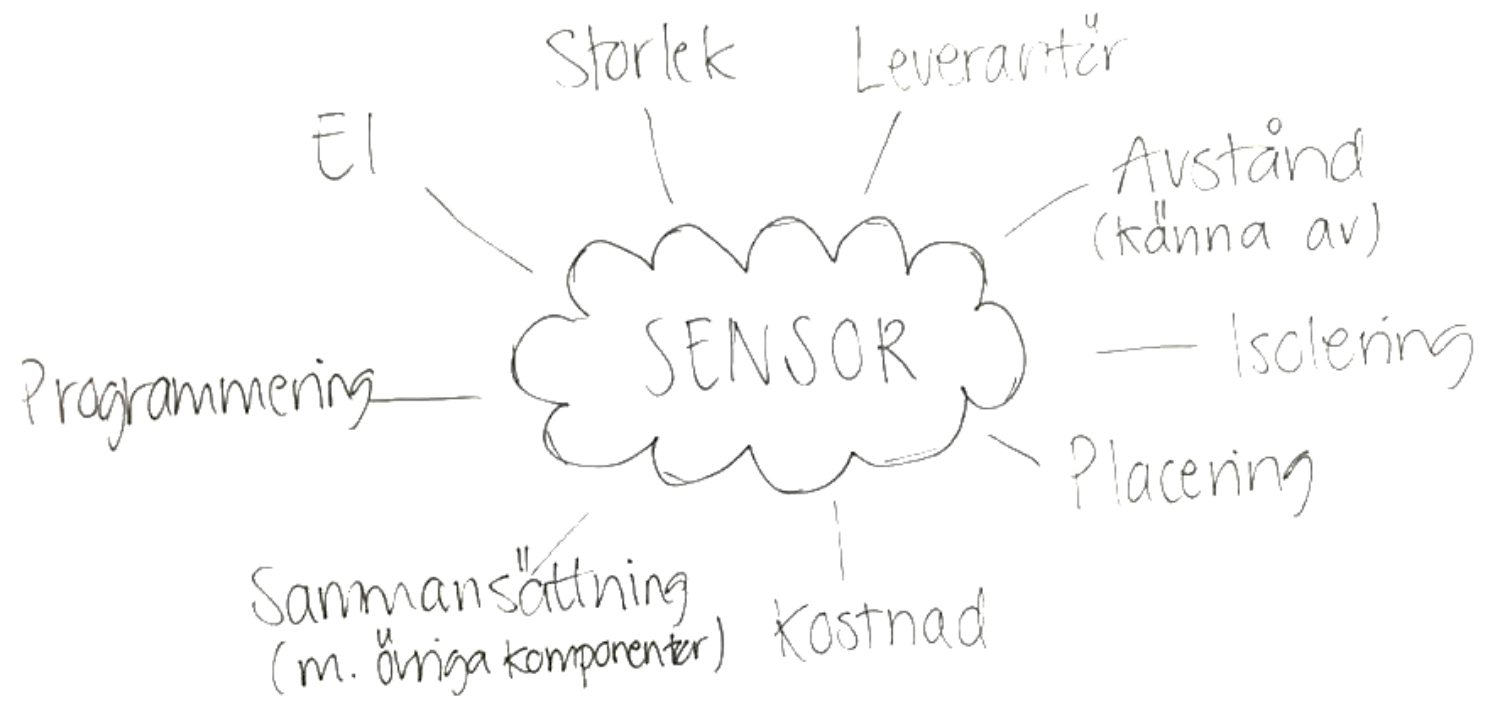

Knapp:

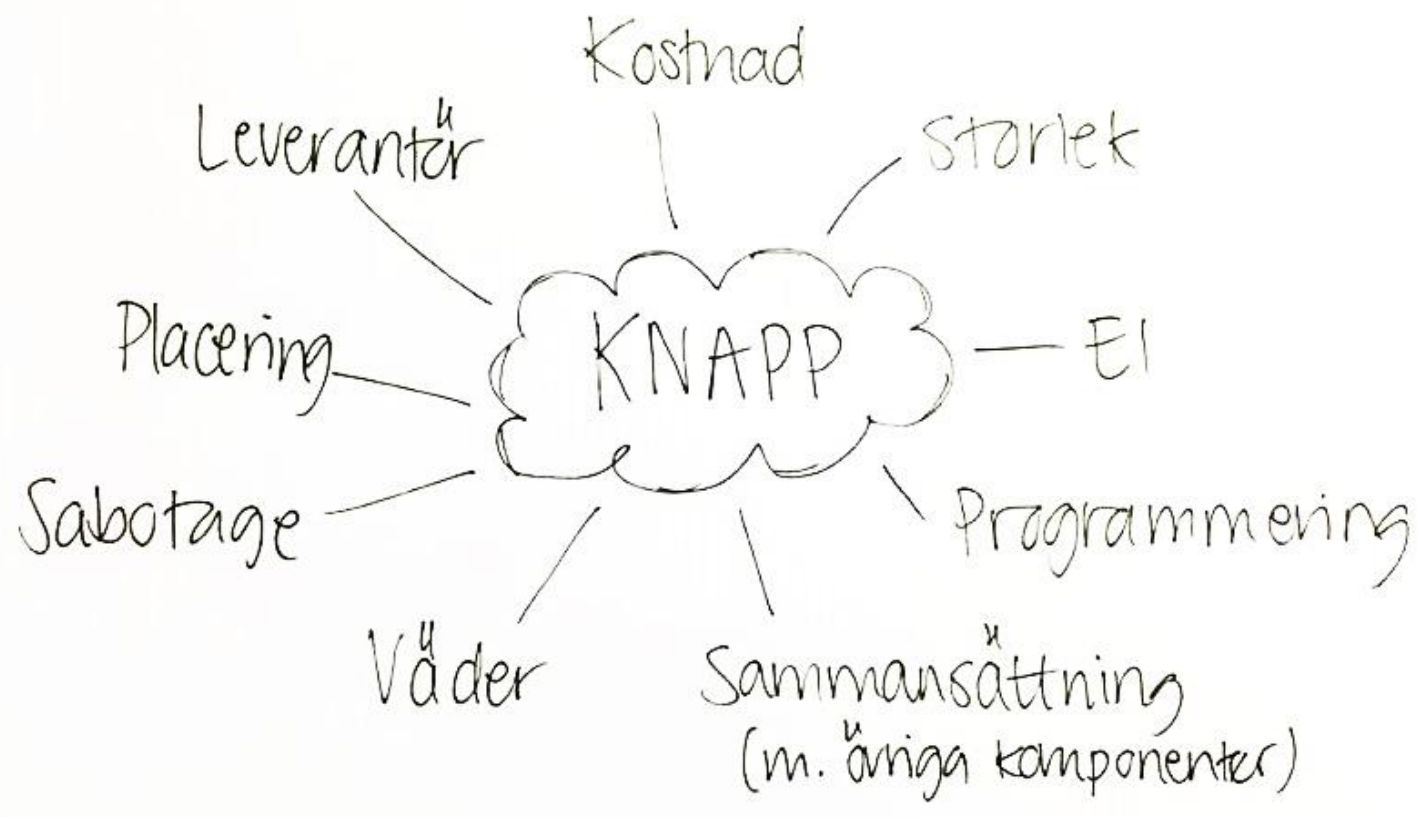

Bilaga 6

5(6) 
Internet:

Sladd?

Uppkoppling - Wi-Fi?

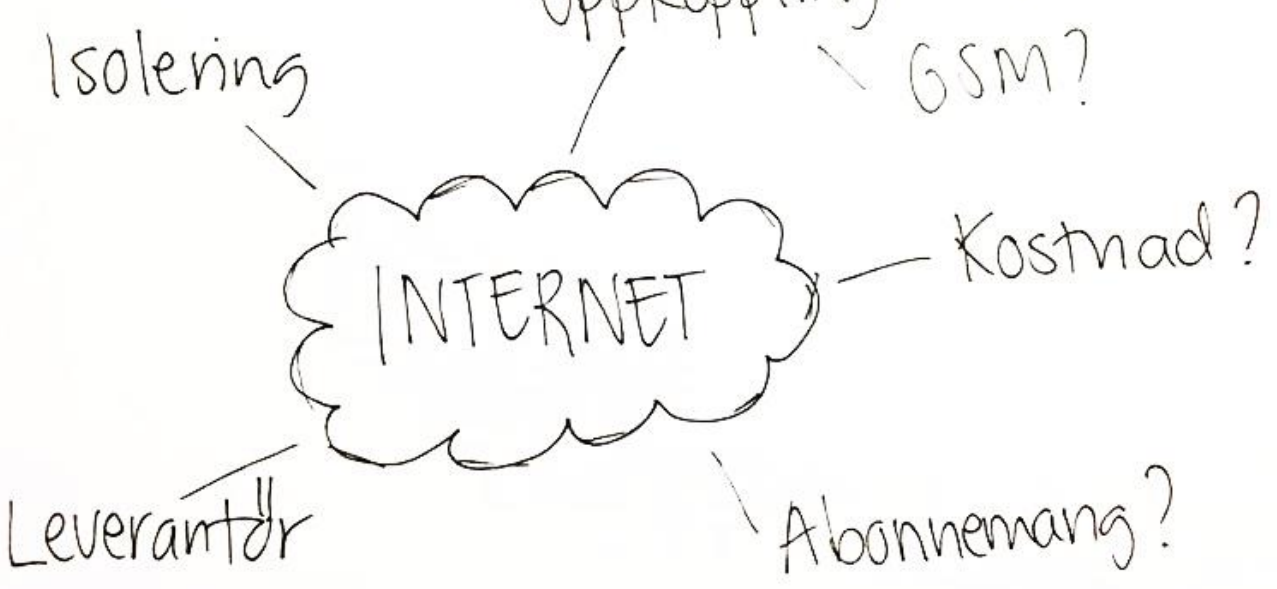

Eltillförsel:

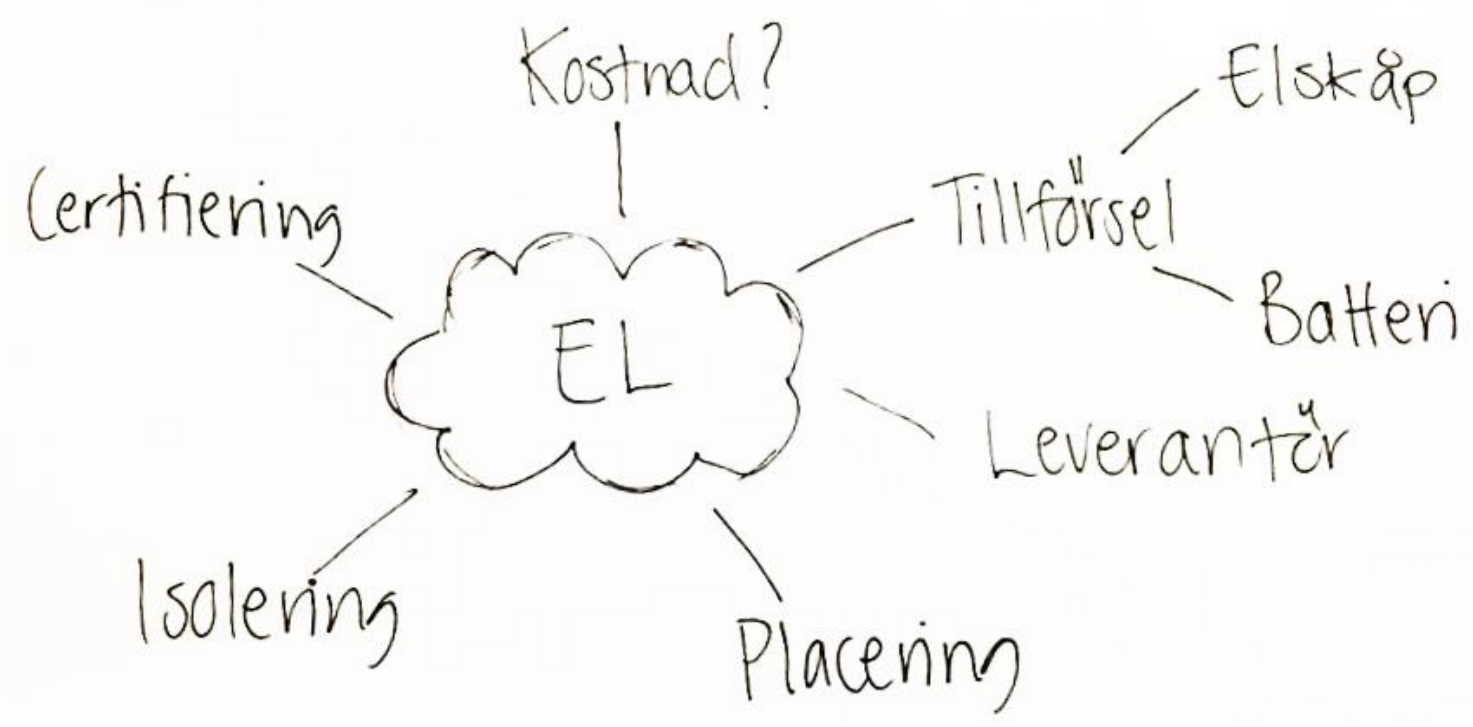

Bilaga 6

6(6) 
Bilaga 7 - Tidsplanering för hösten 2015
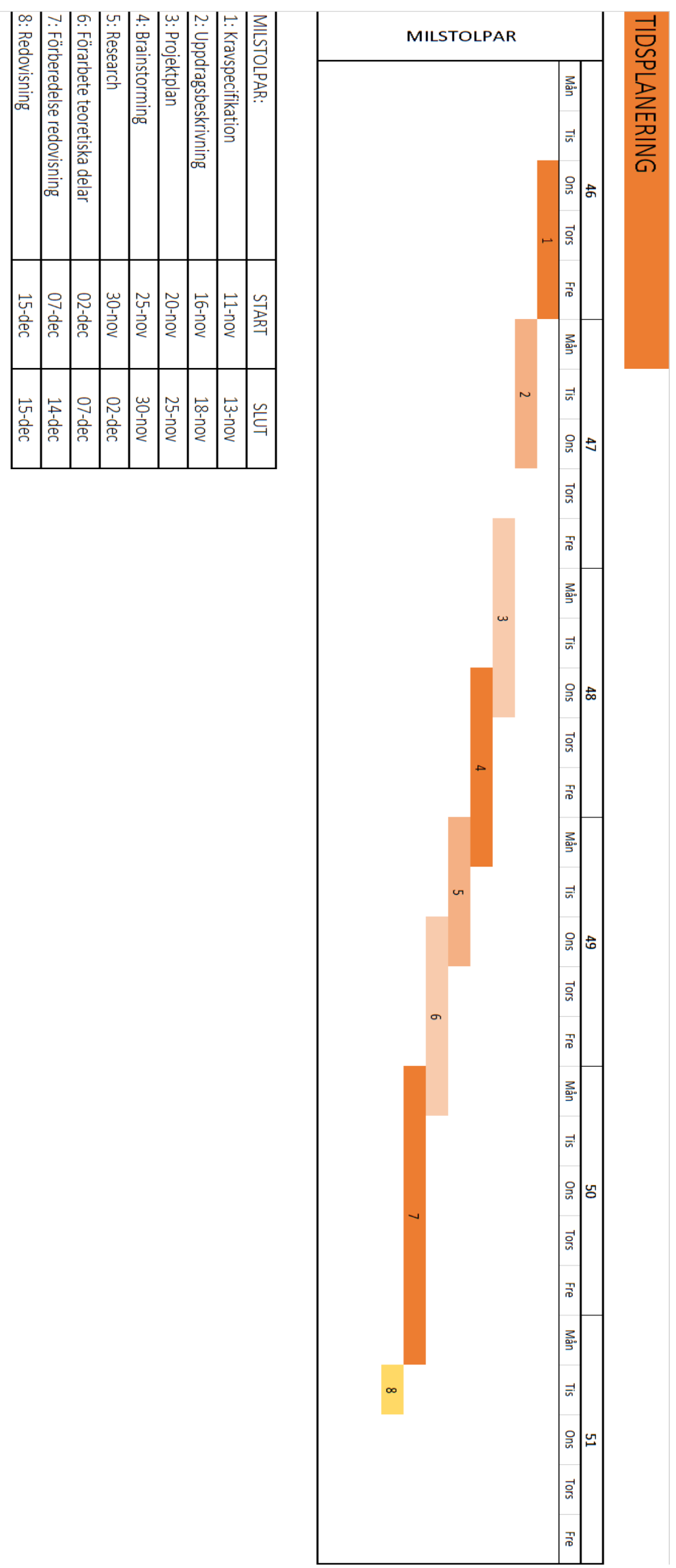
Bilaga 8 - Tidsplaneringar för våren 2016 Skola:




Examensarbete vecka 5-10:

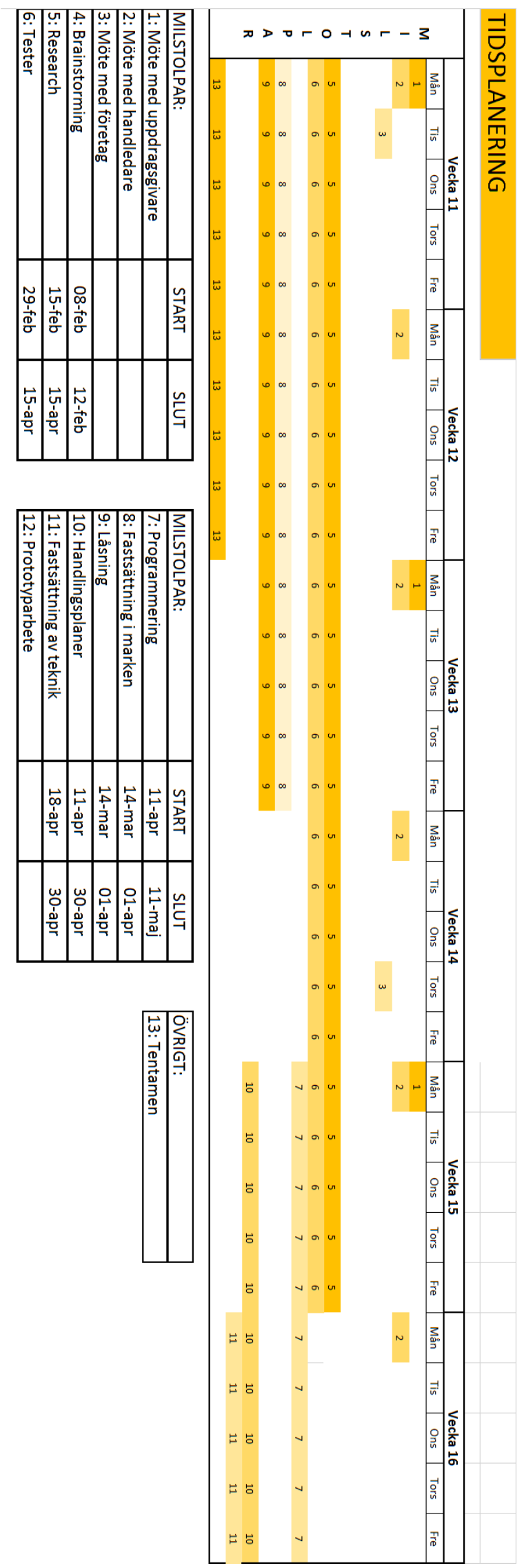


Examensarbete vecka 11-16:

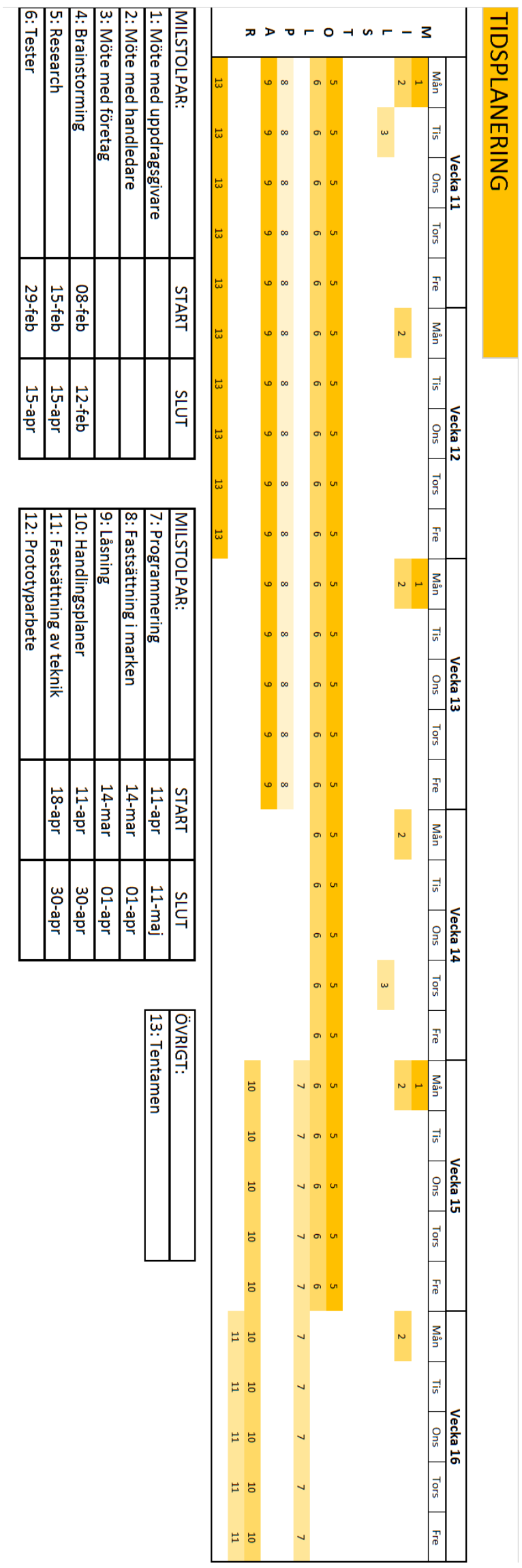


Examenarbete vecka 17-21:

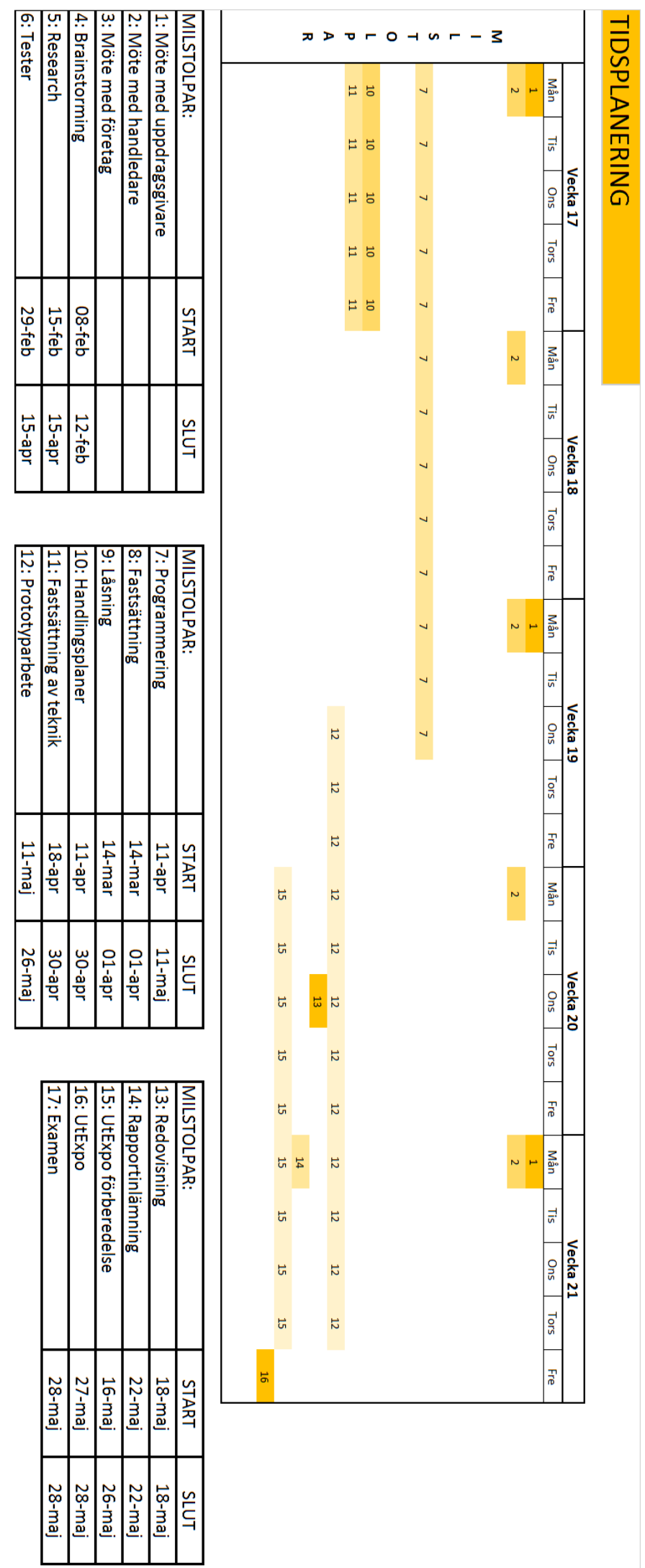


Bilaga 9 - Moodboard

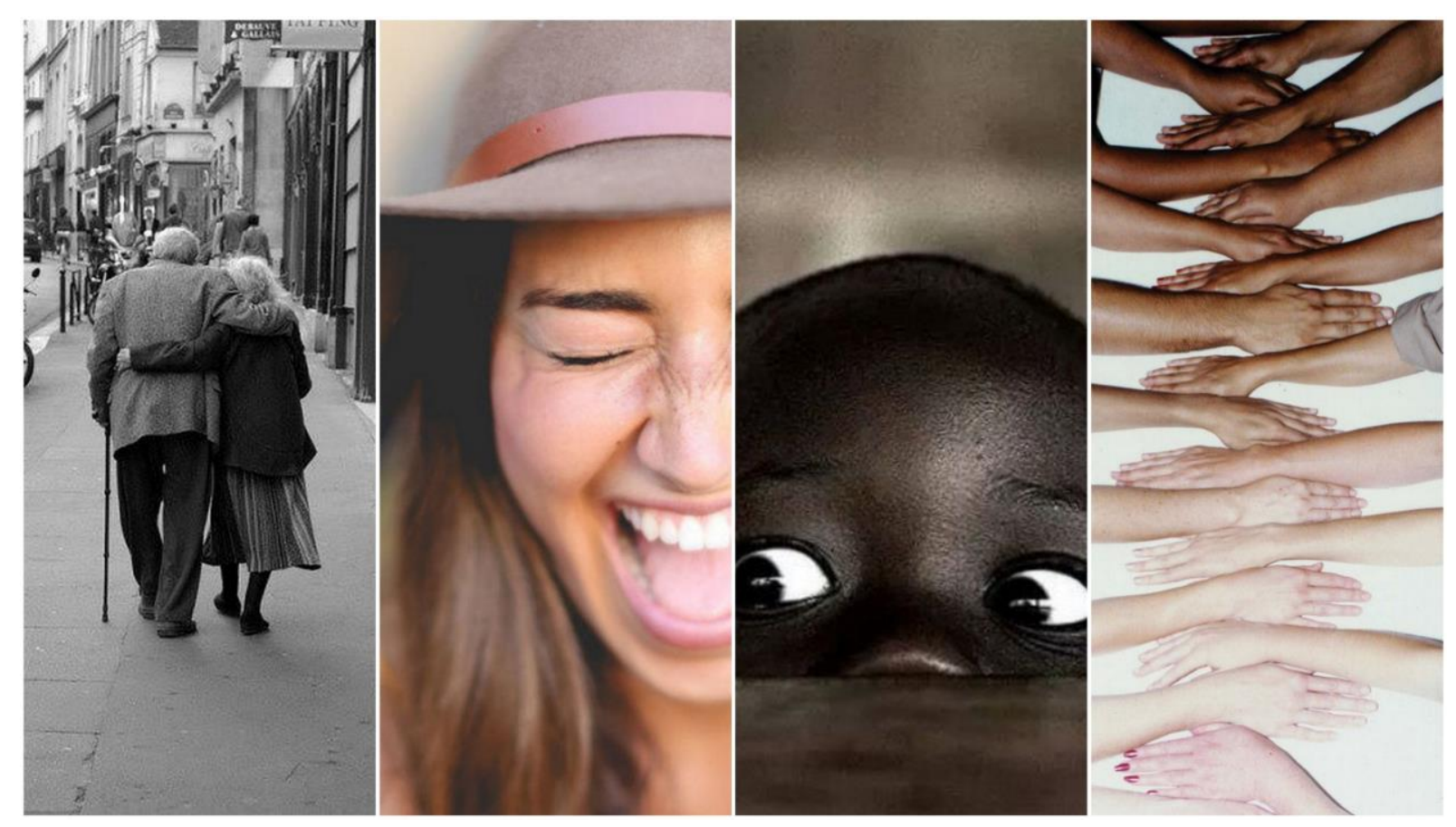


Bilaga 10 - Themeboard

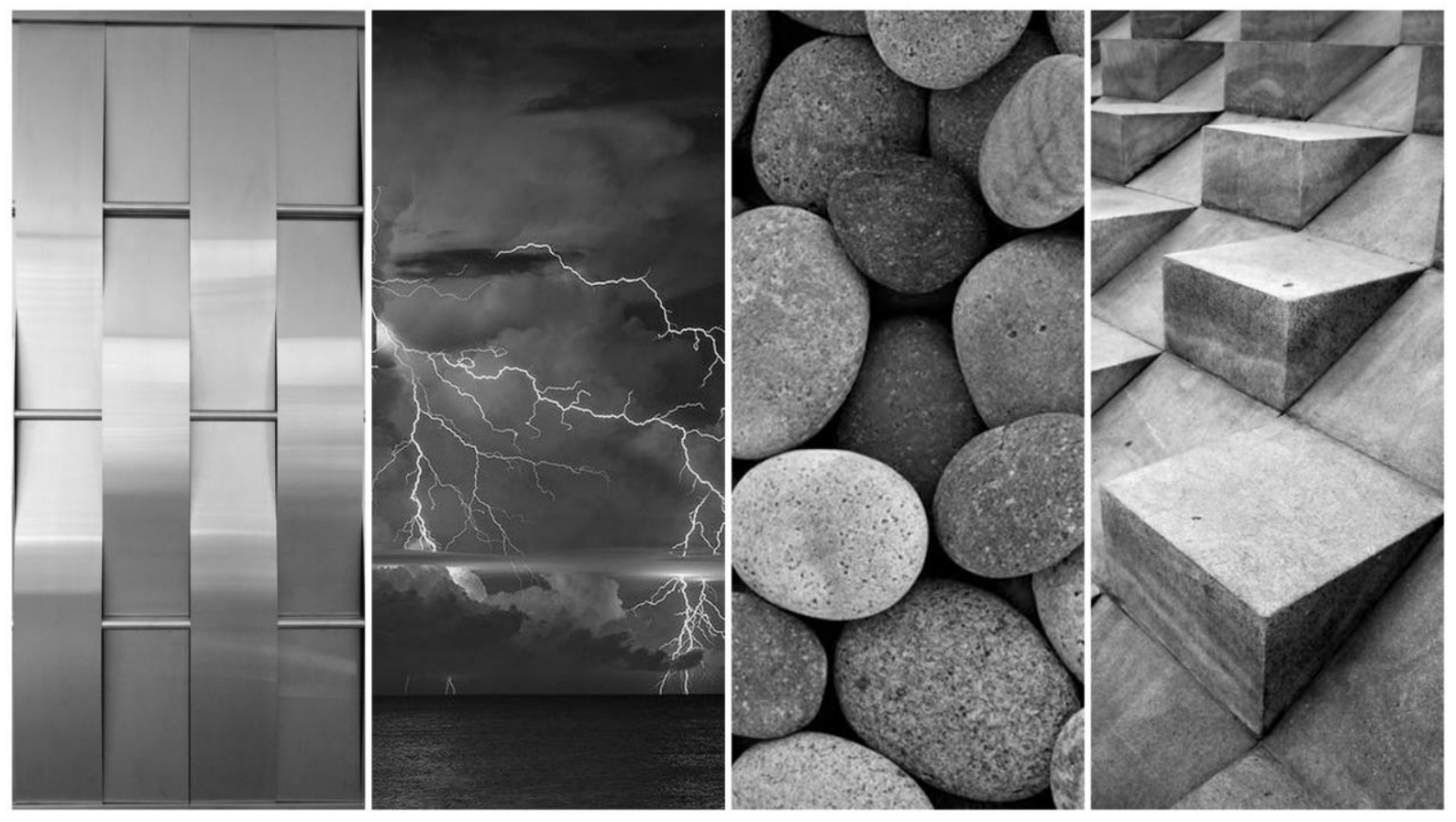



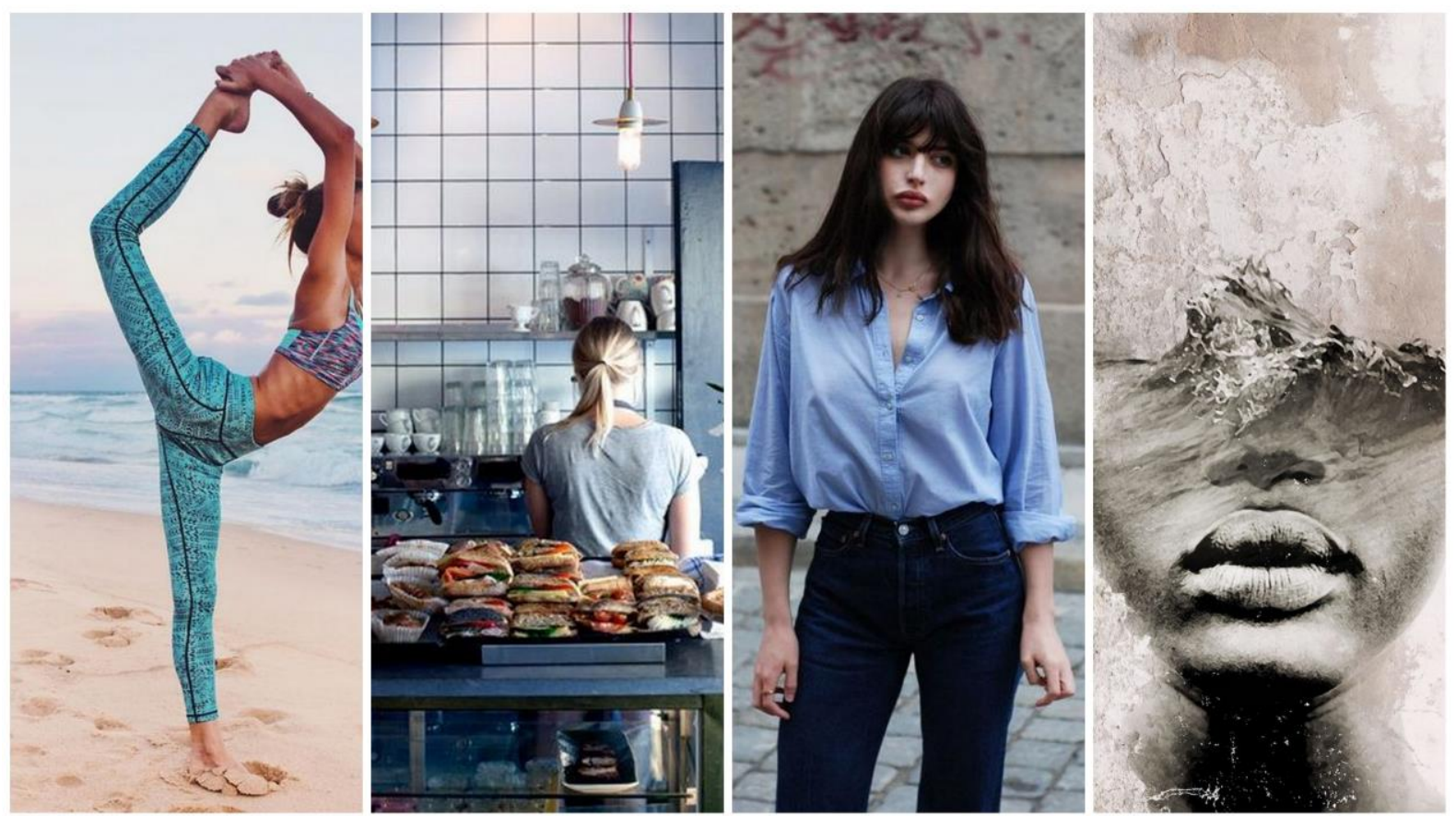

Natalie är 28 år och bor ensam i en tvåa i centrala Malmö. Natalie är väldigt konstintresserad och studerar därför fri konst på konsthögskolan i Malmö. Hon är en kreativ person som gillar att träna, ett av hennes största fritidsintressen är utöva yoga, både hemma och via pass på gymmet. Andra intressen som Natalie har är att baka och fika med sina vänner samt att gå på olika vernissager. Natalie drömmer om att ha en egen vernissage någon gång i livet.

\section{Scenario}

Under en solig sommardag i Malmö är Natalie ute och går en promenad i utkanten av centrum. När Natalie närmar sig centrum ser hon plötsligt en gul konstverk lysa upp av solen några meter fram. Nyfiken som hon är bestämmer hon sig för att gå fram och kolla vad det är för något. När hon närmar sig konstverket ser hon olika symboler och förstår att det är något dolt budskap bakom det hela. Hon uppfattar en högtalar- och mikrofon-symbol och tänker att man kanske ska prata mot konstverket och säger "Hallå?". Några sekunder senare får hon ett svar som säger "Hej, vem är du?". 


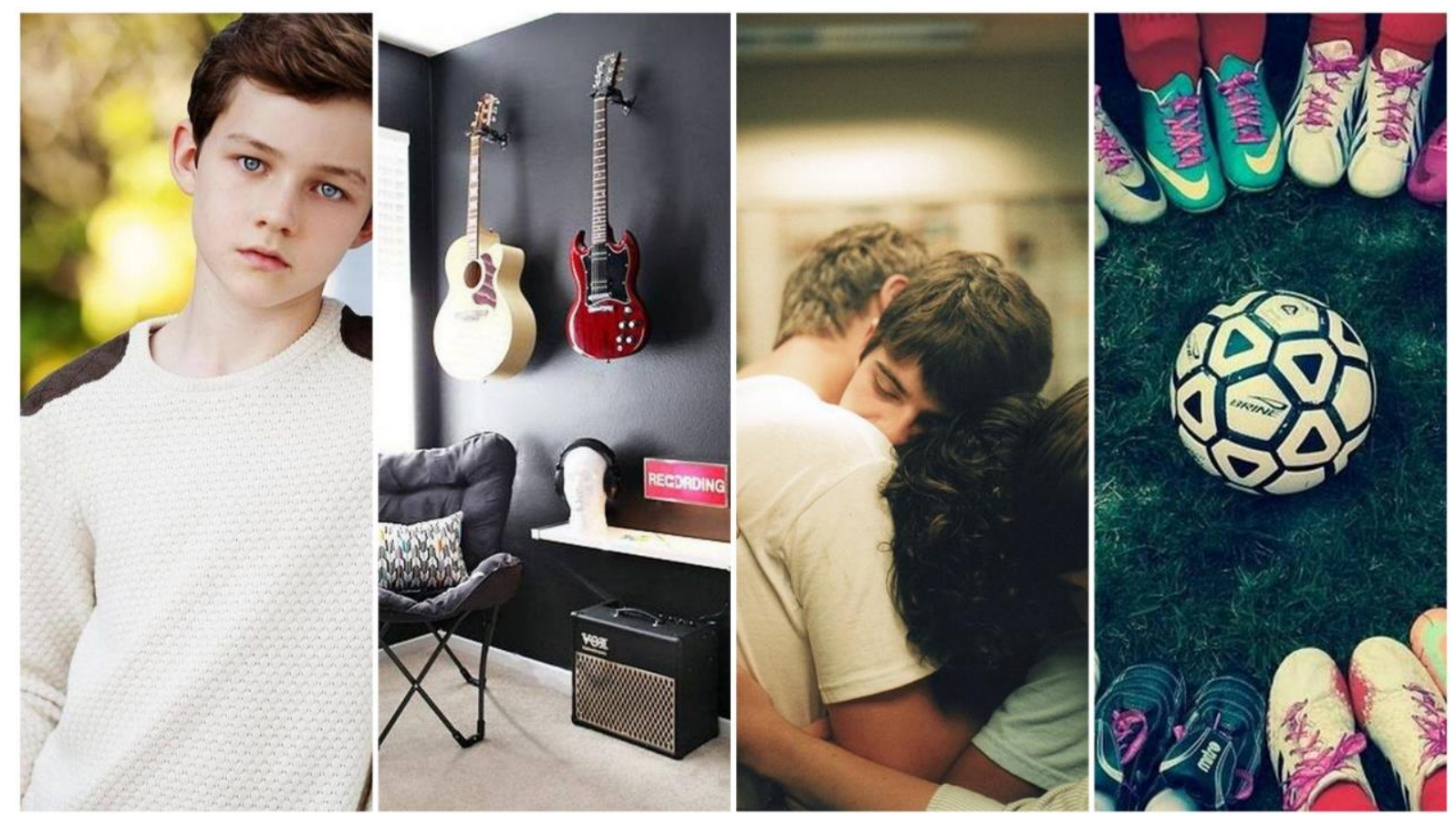

William är en 12 år gammal kille som brinner för att spela fotboll och hänga med kompisar. Utöver det har han ett stort musikintresse och spelar både gitarr och trummor. William bor med sin mamma och pappa och storebror i Halmstad där han går i skola på vardagarna. Fritiden går mestadels åt till fotbollen och musiken och de flesta av hans kompisar från skolan har samma intresse som honom vilket gör att han träffar sina kompisar i stort sett varje dag. William är en charmig kille som har många kompisar och trivs bra i skolan. Han är nyfiken på att upptäcka nya saker och drar sig inte för att prata med människor han inte känner.

\section{Scenario}

William är på väg till fotbollsträningen med bollen under ena armen och fotbollsväskan hängandes över andra axeln. Han är på gott humör och går och nynnar för sig själv i det fina vädret. Plötsligt hör han någon som säger "ha en fortsatt härlig dag" och han vänder sig åt det håll ljudet kommer ifrån. Det enda han ser är en gul konstverk som sticker upp från marken och han går dit för att undersöka vad det kan vara för något. När han kommer närmare ser han en symbol för en högtalare och en för en mikrofon och han tänker att det måste ha varit konstverket som pratat. Nyfiken som han är testar han att säga en mening till konstverket men han hinner inte stå kvar och lyssna om han får något svar då han måste skynda sig vidare till träningen 


\section{Bilaga 12 - Mötesanteckningar}

\section{Mötesanteckningar - EffectSoft 11/2}

- Molntjänst är ett bra alternativ

- Jonas pratade om en kommunikationsenhet och då krävs:

Nätverk - GMS kan vara ett alternativ

Via elnätet var troligtvis svårt

Annat alternativ fria Wi-Fi-zoner som man får kolla upp med kommunen

- Kostnad för EffectSoft: 1050/timme

Kan gå att hitta finansiering/stöd

Tar eventuellt 100-150 timmar (kärnan i molnet + webbsida)

- Kolla upp Konsultstöd på Almi (upp till 150’)

- Kolla med Affärssystemsprogrammet (kontakta H-E)

Lars-Göran Persson är studierektor

- Ta kontakt med HCH (Hälsoteknikcenter) angående sensorer

Ann-Christine Hertz(?)

Wagner(?) är bra på sensorer - Hälsa från Christian på EffectSoft

- Internetchef på Helsingborgs kommun: Joakim Jardenberg(?)

Kontakta honom då han är mycket för "framtiden" 


\section{$\underline{\text { Mötesanteckningar - Daniel 2/3 }}$}

\section{Daniels idé}

- Liknande en mobiltelefon med ett egendesignat kretskort där man då kopplar på högtalare, mikrofon, knapp osv..

- En processor

- Ett minne

- Batteri

- Konstverket ringer upp en typ av växeltjänst och blir sen kopplad till nästa konstverk (den konstverket som är igång och "hämtar hem" meddelandet $\rightarrow$ när den spelat upp meddelandet så övergår den till "sovfunktion”).

\section{Utformning}

- Daniel tänker sig ett långsmalt kretskort med en fram och baksida. Traditionella högtalare kan funka (sådana man kopplar in i datorn) men då behövs endast diskanthögtalaren.

- Istället för Arduino/Raspberry tror han på en mobilvariant med simkort i där de skulle bygga sitt eget kretskort.

- Knappfunktion skulle underlätta för aktiveringen. Alltså att man trycker in knappen när man svarar och när man släpper knappen skickas ljudfilen iväg (är okej med en fördröjning då personen på andra sidan inte märker det ändå)

\section{Mobilvarianten}

- Alternativ 1: En typ av telefonbok som gör att stolparna "ringer till varandra" $\rightarrow$ det konstverk inom nätverket som svarar först får samtalet.

- Alternativ 2: Man lagrar ljudfilerna via en server (dyrare och svårare).

- GRPS-modul $\rightarrow$ Telefonmodul

\section{Väder}

Kyla värre problem än värmen då batterierna blir sämre pga kyla om man ska använda sig av det.

\section{Eltillförsel}

- Daniel vill undvika 230 V (hushållsel) pga då krävs många krav för certifiering för att konstverket inte ska vara strömförande.

- Ett annat exempel på strömtillförsel kan vara solceller (eventuellt en på toppen som är 41x41 mm). Och detta går att räkna på hur mycket den "genererar". Isåfall har man också ett laddningsbart batteri i konstverket som är kopplat till solcellen.

- Man kan använda sig av ett batteri som kallas för superkondensator (idealbatteri = perfekt). Detta är dyrt men kan fungera med ett batteri i mindre storlek. Det lutar åt ett vanligt smartphonebatteri. T ex kan man ha ett stort batteri som byts typ en gång per år.

- Det kommer behövas en "sovfunktion" för konstverket för att den ska kunna ladda sitt batteri. Tanken är att när ett konstverk sover finns det alltid andra som är på så att systemet funkar ändå. Ju fler stolpar som finns $\rightarrow$ desto mer batteritid får alla stolpar. 


\section{Internet}

- Wifi men kanske inte finns överallt är ett alternativ

- Om man har ett vanligt simkort kan det bara kopplas upp till nätet $\rightarrow$ behövs ingen sladd

- 1 MB räcker för att skicka en ljudfil. 30 öre/MB trodde Daniel

- Antingen abonnemang eller om man köper Comviq kontantkort med datamängd istället

\section{Kostnad}

Cirka 20.000 exklusive moms, verkligen inte mer än 30.000

Priset regleras pga materialkostnader osv eller om man behöver köpa in något speciellt Rabatt pga Uare

Ska vara klart till slutredovisningen 20 maj

\section{Kolla upp}

- Vad kostar en växeltjänst?

- Vad händer om konstverket ringer sin egett konstverk?

- Kan man spela in ett tyst "röstmeddelande" till röstbrevlådan?

- Abonnemangstyper

- Fästanordning för kretskortet? "Kila fast det" 


\section{Bilaga 13 - Handlingsplaner}

\section{HANDLINGSPLAN 1: El via kabel}

Handlingsplan 1: El via kabel

Om kunden efterfrågar en annan ellösning än med batteri presenterar projektgruppen nedan en lösning där det finns möjlighet att koppla in konstverket via ett elnät. Då måste dock vissa förändringar göras, både gällande teknik och hur konstverket ska kopplas upp mot elnätet.

\section{TILLVÄGAGÅNGSSÄTT:}

Assisting systems kommer behöva ändra upplägget gällande tekniken. De måste därför tas i kontakt för att byta ut delar av tekniken och programmera om den. Det kommer att tillkomma extra kostnader för detta gällande både materialinköp och arbetskostnad. ${ }^{40}$

Det kommer att krävas en elkabel som är tillräckligt lång för att grävas ner mellan konstverk och elskåp. Elkabeln kommer att löpa inuti konstverket vilket kräver att det finns plats för den i och ut ur konstverket. Den kommer behöva grävas ner i marken och det krävs därför en skyddsslang runt kabeln. Denna finns i olika storlekar och det är viktigt att hitta en som passar. Extra kostnader för material och grävning tillkommer.

För att koppla in ström via elkabel krävs ett elskåp där strömmen kan hämtas. Ett energibolag behöver därmed kontaktas. Lämpligen det energibolag som kommunen anlitar. Strömmen från ett elskåp är på 230 Volt vilket kallas för hushållsel. Det är alltså den strömstyrka som kommer från ett vanligt eluttag. Den teknik som finns i konstverket är dock gjord för att ta emot cirka 12 Volt och därmed krävs en transformator som sänker spänningen till $12 \mathrm{~V} .{ }^{41,42}$

För att konstverket ska bli godkänd för användning i och med att den tar emot så pass kraftig ström krävs certifiering, vilket är ett godkännande av en elektriker som garanterar att konstverket inte kommer att bli till exempel strömförande. Detta görs normalt när testserien av produkten övergår i en produktserie, vilket innebär över cirka 20 stycken produkter. Det kan finnas undantag gällande konst då det inte är en vanlig produkt som ska säljas till privatpersoner eller företag. En undersökning av vad som gäller vid certifiering av en konstprodukt krävs därför. Viktigt att tänka på är dock att certifieringen görs av säkerhetsskäl och är därför en viktig detalj som lämpligen ska genomföras oavsett vad konstverk har för regler gällande detta. ${ }^{43}$

Då andra komplikationer kan tillstöta än för konceptet med solcells- och batteriförsörjning krävs en ny testserie för att garantera att eventuellt nya problem blir åtgärdade. ${ }^{44}$

\section{SAMMANFATTNING:}

Assisting systems kommer behöva programmera om vissa delar. Kostnader för detta och eventuella kostnader för ytterligare material kommer att tillkomma.

Elkabel i rätt längd krävs som dessutom ska passa i konstverket med en skydds-slang runt sig. Den ska grävas ner i marken och extra kostnader för material och grävning tillkommer därför

\footnotetext{
${ }^{40}$ Daniel Pettersson, Assisting Systems

${ }^{41} \mathrm{http}: / /$ www.dinbyggare.se/sa-har-fungerar-husets-elsystem/ (hämtad 2016-05-05)

42 http://www.studera.com/tranano/fysik/Elektricitet/Transf.html (hämtad 2016-05-05)

${ }^{43}$ Daniel Pettersson, Assisting Systems

${ }^{44}$ Ibid
} 
Det behövs tillgång till elskåp. Kontakta därför lämpligt energibolag angående detta.

Transformator krävs för att omvandla strömmen till 12 Volt i konstverket.

Certifiering av elektriker kommer att krävas. Detta kommer att tillkomma ytterligare kostnad för detta. Certifiering görs av säkerhetsskäl och är därför en viktig detalj som inte får glömmas av. Det kan finnas andra regler för certifiering av konstverk, undersök detta i förväg.

Det kommer att krävas en ny testserie av produkten för att åtgärda eventuella fel och brister.

VIKTIGT ATT TÄNKA PA:

Kontakta energibolag

Kontakta Assisting systems

Certifiering

Placering av konstverket kan bli begränsa 


\section{HANDLINGSPLAN 2: El via lyktstolpe}

Om kunden efterfrågar en annan uppladdningsbar batterilösning än via solcell presenterar projektgruppen nedan en lösning där det finns möjlighet att ladda batteriet via en lyktstolpe.

Då måste dock vissa förändringar göras, både gällande teknik och hur konstverket ska kopplas upp mot lyktstolpen.

\section{TILLVÄGAGÅNGSSÄTT:}

Detta alternativ gör att konstverket kan vara strömförsörjande genom ett uppladdningsbart batteri, men det krävs då en elkabel som anslutning.

Lyktstolpar är enbart igång nattetid vilket innebär att det endast går att få ström från dem nattetid. ${ }^{45}$ Alternativet är därmed att ha ett uppladdningsbart batteri i konstverket som är kopplat till en lyktstolpe via kabel och därmed laddas upp under natten. ${ }^{46}$

Till detta krävs hjälp av Assisting systems för att byta ut delar av tekniken och programmera om. Det kommer att tillkomma extra kostnader gällande både materialinköp och arbetskostnad. ${ }^{47}$

Kontakt med kommunen behöver tas angående samråd om hur de får kopplas in i lyktstolpar och om kommunen har några specifika önskemål om vilka lyktstolpar som får användas för detta ändamål. Lämplig kontakt angående detta är den person som har hand om belysning på kommunens teknik- och fritidsförvaltning. Det kan tillkomma kostnader för den el som tas från lyktstolparna på samma sätt som det tillkommer kostnader för den el som tas från ett elskåp enligt Handlingsplan 1.

Det krävs en elkabel för koppling mellan lyktstolpe och konstverk. Denna kabel ska vara nedgrävd i marken och kräver därför skyddsslang runtom. Extra kostnader för material och grävning tillkommer.

På samma sätt som i Handlingsplan 1 kommer strömspänningen vara för hög mellan lyktstolpe och konstverk. En transformator kommer att krävas för att sänka spänningen till 12 Volt. Extra materialkostnader för detta tillkommer. ${ }^{48}$

Certifiering kommer att krävas för att säkerställa att konstverket inte kommer att bli strömförande. Se Handlingsplan 1 för hur detta ska genomföras.

Då andra komplikationer kan tillstöta än för konceptet med solcells- och batteriförsörjning krävs en ny testserie för att garantera att eventuellt nya problem blir åtgärdade.

\section{SAMMANFATTNING:}

Assisting systems kommer behöva programmera om vissa delar. Kostnader för detta och eventuella kostnader för ytterligare material kommer att tillkomma

Elkabel i rätt längd krävs som dessutom ska passa i konstverket med en skyddsslang runt sig. Den ska grävas ner i marken och extra kostnader för material och grävning tillkommer därför

\footnotetext{
${ }^{45}$ Hans Ripén, Teknik och fritidsförvaltningen, Halmstad Kommun

${ }^{46}$ Daniel Pettersson, Assisting Systems

${ }^{47}$ Ibid

${ }^{48}$ Ibid, sid. 52
} 
Det behövs tillgång till en lyktstolpe. Kontakta lämpligen teknik- och fritidsförvaltningen för gällande kommun för samråd angående hur detta får gå till.

Transformator krävs för att omvandla strömmen till 12 Volt i konstverket.

Certifiering av elektriker kommer att krävas. Detta kommer att tillkomma ytterligare kostnader för detta. Certifiering görs av säkerhetsskäl och är därför en viktig detalj som inte făr glömmas av. Det kan finnas andra regler för certifiering av konstverk, undersök detta i förväg.

Det kommer att krävas en ny testserie av produkten för att åtgärda eventuella fel och brister.

VIKTIGT ATT TÄNKA PA:

Kontakta teknik- och fritidsförvaltningen för gällande kommun.

Kontakta Assisting systems.

Certifiering.

Placering av konstverket kan bli begränsad 


\section{HANDLINGSPLAN 3: Internet via kabel}

Om kunden efterfrågar en annan internetlösning än via GPRS-system presenterar projektgruppen nedan en lösning där det finns möjlighet att koppla in konstverket med internetkabel. Då måste dock vissa förändringar göras, både gällande teknik och hur konstverket ska kopplas upp mot internet.

\section{TILLVÄGAGÅNGSSÄTT:}

Internet via kabel kräver en router som en ethernet-kabel kan kopplas till. För att kabeln inte ska behöva vara för lång är det önskvärt att ha en router placerad i närheten av konstverkets placering. Till exempel i ett hus i närheten.

Ethernet-kabeln måste vara placerad i en skyddsslang som passar i konstverket och grävas ner i marken vilket gör att kostnader för material och nedgrävning tillkommer.

Det kommer att krävas ett bredbandsabonnemang vilket lämpligen utfärdas hos samma telebolag som kommunen köper sina bredbandstjänster hos.

Det krävs även för detta ny programmering samt kostnader för arbete och nya material av Assisting systems. Detta på grund av att det inte stämmer överens med det material och den programmering som finns på i konstverket idag.

Då andra komplikationer kan tillstöta än för konceptet med GPRS-system krävs en ny testserie för att garantera att eventuellt nya problem ska bli åtgärdade.

\section{SAMMANFATTNING:}

Det krävs en router och en ethernet-kabel i en tillräckligt lång längd.

Kabeln ska grävas ner i marken vilket dels kräver en skyddsslang runt om och kostnader för nedgrävning.

Ett bredbandsabonnemang krävs.

Ny programmering och materialkostnader för tekniken kommer att tillkomma. Detta ska utföras av Assisting systems.

En ny testserie krävs för att åtgärda eventuella fel och brister.

VIKTIGT ATT TÄNKA PA:

Kontakta telebolag.

Kontakta Assisting Systems.

Placering av konstverk kan bli begränsad 


\section{HANDLINGSPLAN 4: Internet via Wi-Fi}

Om kunden efterfrågar en annan internetlösning än via GPRS-system presenterar projektgruppen nedan en lösning där det finns möjlighet att använda Wi-Fi. Då måste dock vissa förändringar göras, både gällande teknik och hur konstverket ska anslutas till Wi-Fi.

\section{TILLVÄGAGÅNGSSÄTT:}

Internet via Wi-Fi kräver en router som kan ta emot en trådlös signal och en mottagare av signalen i konstverket. Konstverket måste vara placerad på en lämplig plats i närheten av konstverket då signalen måste nås mellan router och konstverk. Alternativt behövs en accesspunkt som förlänger den trådlösa signalen. En accesspunkt kan både användas via trådlöst nätverk och med en ethernet-kabel innan signalen ytterligare förlängs trådlöst. ${ }^{49}$

Det kommer att krävas ett bredbandsabonnemang vilket lämpligen utfärdas hos samma telebolag som kommunen köper sina bredbandstjänster hos.

Konstverkets befintliga teknik idag stämmer inte ihop med denna inkoppling. Det kommer därför att krävas nytt material för tekniken och ny programmering utfärdat av Assisting systems.

Då andra komplikationer kan tillstöta än för konceptet med GPRS-system krävs en ny testserie för att garantera att eventuellt nya problem ska bli åtgärdade.

\section{SAMMANFATTNING:}

Det krävs en trådlös router med en lång räckvidd. Alternativt en inkoppling av en accesspunkt för att förlänga signalen ytterligare. Till detta krävs en ethernet-kabel eller en trådlös anslutning.

Om en ethernet-kabel för en del av sträckan väljs, se Handlingsplan 3.

Ett bredbandsabonnemang krävs.

Ny programmering och materialkostnader för tekniken kommer att tillkomma. Detta ska utföras av Assisting systems.

En ny testserie krävs för att åtgärda eventuella fel och brister.

\section{VIKTIGT ATT TÄNKA PA:}

Kontakta telebolag.

Kontakta Assisting Systems.

Placering av konstverket kan bli begränsad om en del av internetanslutningen sker via ethernet-kabel

\footnotetext{
${ }^{49}$ https://www.kjell.com/se/fraga-kjell/hur-funkar-det/natverk/hemnatverk/battre-tradlos-tackning (hämtad 201605-03)
} 
Bilaga 14 - Ritningar/bilder

Bilder gjorda av Robert Hais
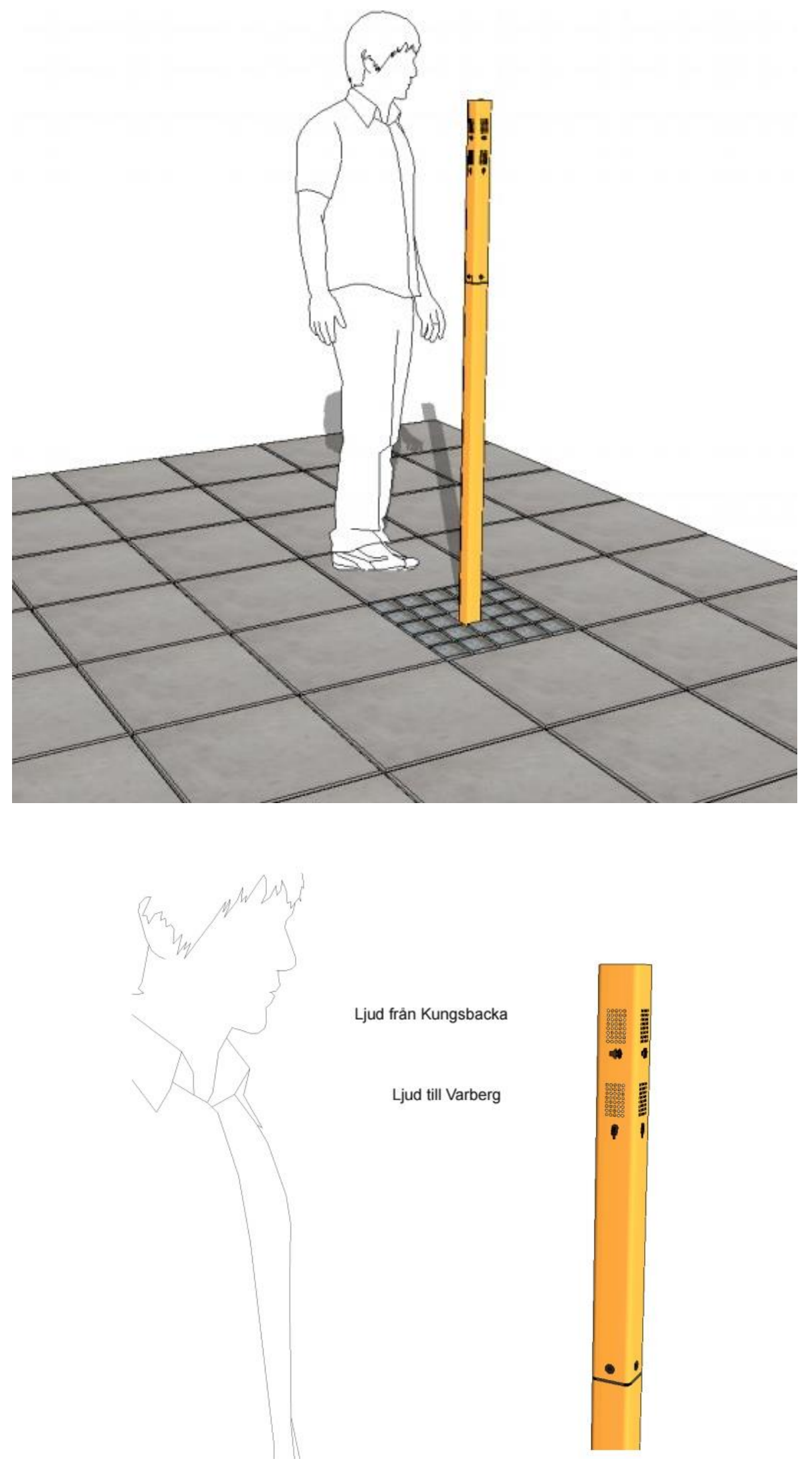


Emma Bäckman

Anna W estberg

Besöksadress: Kristian IV:s väg 3

Postadress: Box 823, 30I 18 Halmstad

Telefon: 035-16 7I 00

HÖGSKOLAN

I HALMSTAD

E-mail: registrator@hh.se www.hh.se 